\title{
Biological production in two contrasted regions of the Mediterranean Sea during the oligotrophic period: an estimate based on the diel cycle of optical properties measured by BioGeoChemical-Argo profiling floats
}

\author{
Marie Barbieux ${ }^{1}$, Julia Uitz ${ }^{1}$, Alexandre Mignot ${ }^{2}$, Collin Roesler ${ }^{3}$, Hervé Claustre ${ }^{1}$, Bernard Gentili ${ }^{1}$, \\ Vincent Taillandier ${ }^{1}$, Fabrizio D'Ortenzio ${ }^{1}$, Hubert Loisel ${ }^{4}$, Antoine Poteau ${ }^{1}$, Edouard Leymarie ${ }^{1}$, \\ Christophe Penkerc'h ${ }^{1}$, Catherine Schmechtig ${ }^{5}$, and Annick Bricaud ${ }^{1}$ \\ ${ }^{1}$ Laboratoire d'Océanographie de Villefranche (LOV), Sorbonne Université, CNRS, \\ 181 Chemin du Lazaret, 06230 Villefranche-sur-Mer, France \\ ${ }^{2}$ Mercator Ocean, 31520 Ramonville-Saint-Agne, France \\ ${ }^{3}$ Earth and Oceanographic Science, Bowdoin College, Brunswick, Maine 04011, USA \\ ${ }^{4}$ Laboratoire d'Océanologie et de Géosciences, Université du Littoral Côte d'Opale, \\ Université de Lille, CNRS, 59000 Lille, France \\ ${ }^{5}$ OSU Ecce Terra, UMS 3455, Sorbonne Université, CNRS, 4 place Jussieu, 75252 Paris CEDEX 05, France \\ Correspondence: Julia Uitz (julia.uitz@imev-mer.fr)
}

Received: 7 May 2021 - Discussion started: 18 May 2021

Revised: 10 December 2021 - Accepted: 3 January 2022 - Published: 24 February 2022

\begin{abstract}
This study assesses marine community production based on the diel variability of bio-optical properties monitored by two BioGeoChemical-Argo (BGC-Argo) floats. Experiments were conducted in two distinct Mediterranean systems, the northwestern Ligurian Sea and the central Ionian Sea, during summer months. We derived particulate organic carbon (POC) stock and gross community production integrated within the surface, euphotic and subsurface chlorophyll maximum (SCM) layers, using an existing approach applied to diel cycle measurements of the particulate beam attenuation $\left(c_{\mathrm{p}}\right)$ and backscattering $\left(b_{\mathrm{bp}}\right)$ coefficients. The diel cycle of $c_{\mathrm{p}}$ provided a robust proxy for quantifying biological production in both systems; that of $b_{\text {bp }}$ was comparatively less robust. Derived primary production estimates vary by a factor of 2 depending upon the choice of the bio-optical relationship that converts the measured optical coefficient to POC, which is thus a critical step to constrain. Our results indicate a substantial contribution to the water column production of the SCM layer (16\%-42\%), which varies largely with the considered system. In the Ligurian Sea, the SCM is a seasonal feature that behaves as a subsurface biomass maximum (SBM) with the ability to respond to episodic abi-
\end{abstract}

otic forcing by increasing production. In contrast, in the Ionian Sea, the SCM is permanent, primarily induced by phytoplankton photoacclimation, and contributes moderately to water column production. These results clearly demonstrate the strong potential for transmissometers deployed on BGCArgo profiling floats to quantify non-intrusively in situ biological production of organic carbon in the water column of stratified oligotrophic systems with recurring or permanent SCMs, which are widespread features in the global ocean.

\section{Introduction}

Primary production is an essential process in the global ocean carbon cycle (Field et al., 1998). As a major driver of the biological carbon pump, this biogeochemical process plays a critical role in the regulation of Earth's climate (e.g., Sarmiento and Siegenthaler, 1992; Falkowski, 2012). Hence, quantifying primary production as a function of time and space in the ocean stands as a major challenge in the context of climate change. The balance between gross pri- 
mary production and community respiration in the ocean determines the trophic status of marine systems, i.e., whether the system acts as a source or a sink of carbon (Williams, 1993). This balance depends on the considered region and varies substantially according to spatial and temporal scales (Geider et al., 1997; Duarte and Agusti, 1998; del Giorgio and Duarte, 2002). It is therefore necessary to develop capabilities not only for assessing primary production on a global scale but also for characterizing and quantifying the biogeochemical functioning of marine ecosystems at smaller spatial and temporal scales (Serret et al., 1999; González et al., 2001, 2002).

Traditionally, primary production measurements have been based on in situ or in vitro incubation experiments (i.e., on board the ship, under controlled conditions) coupled with isotopic carbon analysis (Nielsen, 1952; Fitzwater et al., 1982; Dandonneau, 1993; Barber and Hitling, 2002) or measurements of oxygen concentration (Williams and Jenkinson, 1982; Williams and Purdie, 1991). These methods involve seawater sampling during field campaigns, sample manipulation and subsequent laboratory analyses, which are both time consuming and require strong technical expertise. As a result, the availability of field primary production measurements is relatively limited in terms of spatial and temporal coverage, which hinders the possibility of extrapolation to other systems or to larger spatial and temporal scales for modeling purposes. Active chlorophyll fluorescence techniques, such as fast-repetition-rate fluorometry (FRRF), yield in situ phytoplankton physiological parameters, which when combined with appropriate modeling, provide estimates of derived primary production (e.g., Kolber and Falkowski, 1993; Smyth et al., 2004). This technique has the major advantage of providing an instantaneous, fine-scale estimation of primary production in a non-invasive manner. Nevertheless, it is subject to assumptions and uncertainties, in particular related to the interpretation of fluorescence-light curve information in terms of carbon fixation, that still limit its use (see, e.g., Suggett et al., 2004; Corno et al., 2005; Regaudie-de-Gioux et al., 2014, and references herein).

Bio-optical primary production models coupled with ocean color satellite imagery represent another approach for obtaining primary production estimates (Morel, 1991; Longhurst et al., 1995; Antoine et al., 1996; Behrenfeld et al., 2002). Such models are extremely valuable for assessing primary production with a large spatial coverage and over a broad range of temporal scales (Sathyendranath et al., 1995; Uitz et al., 2010; Chavez et al., 2013). Yet, most of these models suffer from several sources of uncertainty that can generate potential errors in the production estimates (e.g., Sarmiento et al., 2004; Saba et al., 2010, 2011). Sources of uncertainty include, in particular, the extrapolation of the satellite chlorophyll product, which is weighted to the upper portion of the euphotic zone, to the entirety of the productive region of the water column not sensed remotely. In addition, the in situ-based parameterization of phytoplankton photo- physiology tends to lack robustness when applied to large (regional or global) scales and over seasonal to interannual timescales.

Diel cycles observed in bio-optical properties provide a less empirical and more mechanistic approach to assess biological production. In a seminal paper published in 1989, Siegel et al. observed the in situ diurnal variability of the particulate beam attenuation coefficient $\left(c_{\mathrm{p}}\right)$ and used it as a surrogate for the diurnal variations in the abundance of biogenic particles and associated production in the oligotrophic North Pacific Ocean. Several studies subsequently pursued the investigation of the diurnal variability of marine bio-optical properties as a means for determining non-intrusively in situ biological production (e.g., Stramska and Dickey, 1992; Durand and Olson, 1996; Claustre et al., 1999, 2008; Gernez et al., 2011; White et al., 2017; Briggs et al., 2018).

Among this large body of literature, Claustre et al. (2008) carried further the principle of the Siegel et al. (1989) approach for application to the subtropical South Pacific Ocean. Based upon the generally observed relationship between the $c_{\mathrm{p}}$ coefficient and the stock of particulate organic carbon, POC (e.g., Stramski et al., 1999; Gardner et al., 2006), Claustre et al. (2008) assumed that diel variations in $c_{\mathrm{p}}$ reflect diel variations in POC. Thus, the observed daytime increase and nighttime decrease in $c_{\mathrm{p}}$-derived POC are used to estimate gross community production, community losses and, assuming equivalent day and night losses, net community production. Because the $c_{\mathrm{p}}$ coefficient is not specific to phytoplankton but includes the POC contribution of both autotrophic and heterotrophic particles, the $c_{\mathrm{p}}$-based method yields an estimate of community production.

Two studies (Kheireddine and Antoine, 2014; Barnes and Antoine, 2014) extended the approach to the particulate backscattering coefficient $\left(b_{\mathrm{bp}}\right)$. The application opens up opportunities for assessing community production from geostationary ocean color satellite observations, from which a nearly continuous daytime $b_{\text {bp }}$ coefficient can be retrieved. Both studies focused on surface data obtained from moored observations from the Ligurian Sea (northwestern Mediterranean) and found that the diel cycle of $b_{\mathrm{bp}}$ may not necessarily be interchanged with that of $c_{\mathrm{p}}$, which calls for further investigations.

The optics-based approach has proven to be particularly relevant for appraising particulate biological production in stratified oligotrophic systems such as subtropical gyres (e.g., Siegel et al., 1998; Claustre et al., 2008; White et al., 2017). Interestingly, in such systems, the biological production of organic carbon is difficult to quantify and potentially underestimated by ${ }^{14} \mathrm{C}$ incubation methods (Juranek and Quay, 2005; Quay et al., 2010). This might be attributed to an inadequacy of traditional measurement methods for adequately capturing the spatial and temporal heterogeneity of biological production that may exhibit local or episodic events (Karl et al., 2003; Williams et al., 2004; McGillicuddy, 2016). Moreover, in stratified oligotrophic 
systems, the vertical distribution of phytoplankton is frequently characterized by the presence of a deep chlorophyll maximum (DCM), also referred as subsurface chlorophyll maximum (SCM; e.g., Cullen, 1982; Hense and Beckmann, 2008; Cullen, 2015; Mignot et al., 2014). SCMs are not necessarily resolved by in situ discrete sampling and cannot be observed from ocean color satellites that are limited to the surface ocean. They are typically attributed to phytoplankton photoacclimation, the physiological process by which phytoplankton cells adjust to light limitation by increasing their intracellular chlorophyll content without a concomitant increase in carbon (Kiefer et al., 1976; Cullen, 1982; Fennel and Boss, 2003; Letelier et al., 2004; Dubinsky and Stambler, 2009). Yet, SCMs resulting from an actual increase in phytoplankton (carbon) biomass, and so referred to as subsurface biomass maximum (SBM), have also been observed episodically and/or seasonally in oligotrophic regions of the global ocean (Beckmann and Hense, 2007; Mignot et al., 2014; Barbieux et al., 2019; Cornec et al., 2021). Considering the large $(45 \%)$ surface areas covered by stratified oligotrophic regions in the global ocean (McClain et al., 2004), improving the quantification of biological production of organic carbon and characterizing the contribution of SCMs to the water column production in such regions are critical. For this purpose, in situ diel-resolved measurements with high spatiotemporal resolution in the entire water column represent an intriguing opportunity of vital importance.

In this study, we exploit summertime observations acquired by two BioGeoChemical-Argo (BGC-Argo) profiling floats deployed in contrasted systems of the Mediterranean Sea. This offers a unique opportunity for pursuing the exploration of the bio-optical diel-cycle-based approach to biological production in oligotrophic environments. One of the two BGC-Argo floats was deployed in the Ligurian Sea in the vicinity of the BOUSSOLE fixed mooring (BOUée pour l'acquiSition d'une Série Optique à Long termE; Antoine et al., 2008). This area is representative of a seasonally stratified oligotrophic system with a potentially productive SCM (e.g., Mignot et al., 2014; Barbieux et al., 2019) that follows a recurrent spring bloom. The second float was deployed in the Ionian Sea (central Mediterranean) as part of the PEACETIME (ProcEss studies at the Air-sEa Interface after dust deposition in the MEditerranean sea) project (Guieu et al., 2020a). The Ionian Sea is a nearly permanent oligotrophic system (e.g., Lavigne et al., 2015) with an SCM induced mostly by photoacclimation of phytoplankton cells without a concomitant increase of carbon biomass (e.g., Mignot et al., 2014; Barbieux et al., 2019).

The BGC-Argo profiling floats used in this study measured, among a suite of physical and biogeochemical properties, the $c_{\mathrm{p}}$ and $b_{\mathrm{bp}}$ coefficients and were both programmed to sample the entire water column at a high temporal resolution (four vertical profiles every $24 \mathrm{~h}$ ), in order to monitor the diel variations of the bio-optical properties. We applied, for the first time, a modified version of the method of Claustre et al. (2008) to the diel $c_{\mathrm{p}}$ and $b_{\mathrm{bp}}$ measurements acquired by the BGC-Argo floats to derive community production. Using this dataset, we (1) assess the relevance of the diel-cyclebased method for estimating biological production of organic carbon in the considered regions and discuss the applicability of the method to $b_{\mathrm{bp}}$, in addition to $c_{\mathrm{p}}$; (2) investigate the regional and vertical variability of the production estimates with a focus on the SCM layer in relation to the biological and abiotic context; and (3) discuss the relative contribution of the SCM layer to the water column community production.

\section{Data and methods}

\subsection{Study region}

The Mediterranean Sea provides a unique environment for investigating the biogeochemical functioning of oligotrophic systems that exhibit either a seasonal or permanent SCM. The Mediterranean is a deep ocean basin characterized by a west-to-east gradient in nutrients and chlorophyll $a$ concentration (e.g., Dugdale and Wilkerson, 1988; Bethoux et al., 1992; Antoine et al., 1995; Bosc et al., 2004; D’Ortenzio and D'Alcalà, 2009) associated with a deepening of the SCM (Lavigne et al., 2015; Barbieux et al., 2019). The Ionian Sea in the eastern Mediterranean is defined as permanently oligotrophic, with the SCM settled at depth over the whole year. This system represents the oligotrophic end-member type of SCM (Barbieux et al., 2019), much like the subtropical South Pacific Ocean gyre. By contrast, the Ligurian Sea in the western Mediterranean is seasonally productive akin to a temperate system (e.g., Casotti et al., 2003; Marty and Chiavérini, 2010; Siokou-Frangou et al., 2010; Lavigne et al., 2015). The mixed layer deepens significantly during the winter period, inducing seasonal renewal of nutrients in the surface layer that supports the spring bloom (Marty et al., 2002; Lavigne et al., 2013; Pasqueron de Fommervault et al., 2015; Mayot et al., 2016). After the seasonal bloom, the SBM intensifies throughout the summer and into early fall. This system represents the temperate end-member type of SCM.

\subsection{BGC-Argo multi-profiling floats and data processing}

We deployed BGC-Argo floats programmed for "multiprofile" sampling in each of these two regions (Fig. 1). The Ligurian Sea float (hereafter fLig, WMO: 6901776) was deployed in the vicinity of the BOUSSOLE fixed mooring $\left(7^{\circ} 54^{\prime} \mathrm{E}, 43^{\circ} 22^{\prime} \mathrm{N}\right)$ during one of the monthly cruises of the BOUSSOLE program (Antoine et al., 2008) and profiled from 9 April 2014 to 15 March 2015. For the purpose of this study focusing on oligotrophic systems, we selected the fLig float measurements acquired during the time period 24 May to 13 September 2014 to coincide in months with the Ionian Sea float time series. The Ionian Sea float 


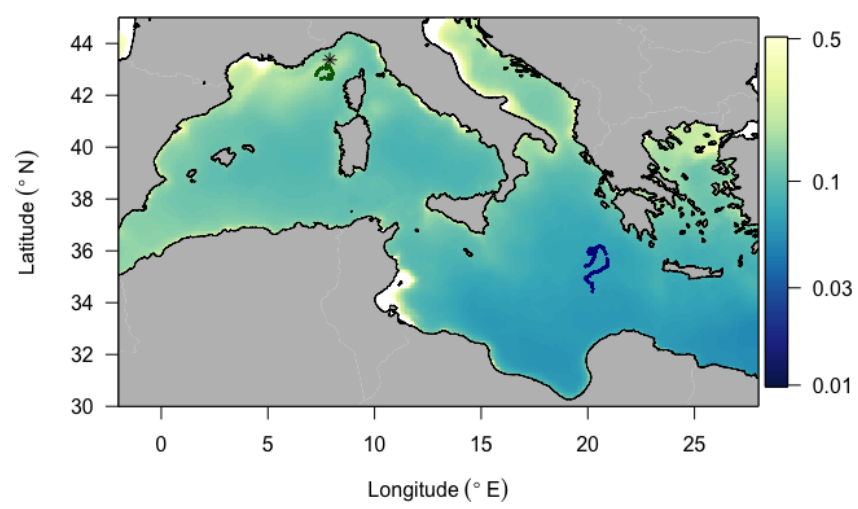

Figure 1. Trajectories of the two BGC-Argo profiling floats fLig (WMO: 6901776) and fIon (WMO: 6902828) deployed, respectively, in the Ligurian Sea (green) and the Ionian Sea (blue), superimposed onto a $9 \mathrm{~km}$ resolution summer climatology of surface chlorophyll $a$ concentration (in $\mathrm{mg} \mathrm{m}^{-3}$ ) derived from MODIS Aqua ocean color measurements. The asterisk-shaped symbol indicates the geographic location of the BOUSSOLE site.

(hereafter fIon, WMO: 6902828) was deployed as part of the PEACETIME project (Guieu et al., 2020a). We used the fIon float measurements acquired during the time period 28 May to 11 September 2017. Thus, although collected in different years, the datasets arise from similar seasonal contexts.

The BGC-Argo floats used in this study are of the type "PROVOR CTS4" (nke Instrumentation, Inc.). They were both equipped with the following sensors and derived data products: (1) a CTD (conductivity-temperature-depth) sensor for depth, temperature and salinity; (2) a "remA" combo sensor that couples a Satlantic OCR-504 (for downwelling irradiance at three wavelengths in addition to photosynthetic available radiation, PAR) and a WET Labs ECO Puck Triplet (for both chlorophyll $a$ (excitation and emission wavelengths of $470 \mathrm{~nm}$ and $695 \mathrm{~nm}$ ) and colored dissolved organic matter (CDOM; $370 \mathrm{~nm} / 460 \mathrm{~nm}$ ) fluorescence and particulate backscattering coefficient at $700 \mathrm{~nm}$ ); and (3) a WET Labs C-Rover (for particulate beam attenuation coefficient at $660 \mathrm{~nm}, 25 \mathrm{~cm}$ pathlength). Data were collected along water column profiles from $1000 \mathrm{~m}$ up to the surface with a vertical resolution of $10 \mathrm{~m}$ between 1000 and $250 \mathrm{~m}$, $1 \mathrm{~m}$ between 250 and $10 \mathrm{~m}$, and $0.2 \mathrm{~m}$ between $10 \mathrm{~m}$ and the surface. First, the BGC-Argo raw counts were converted into geophysical units by applying factory calibration. Second, we applied corrections following the BGC-Argo QC (quality control) procedures (Schmechtig et al., 2015, 2016; Organelli et al., 2017).

Factory-calibrated chlorophyll fluorescence requires additional corrections for determining the chlorophyll $a$ concentration (Chl). Values collected during daylight hours were corrected for non-photochemical quenching following Xing et al. (2012). A global analysis of factory-calibrated chlorophyll fluorescence measured with WET Labs ECO sensors relative to concurrent chlorophyll $a$ concentrations, deter- mined by high-performance liquid chromatography (HPLC), yielded a global overestimate bias of 2 (Roesler et al., 2017), with statistically significant regional biases varying between 0.5 and 6 . The Mediterranean Sea is known to show very small regional variations of the fluorescence-to-Chl ratio (Taillandier et al., 2018), with a mean value close to $2(1.66 \pm 0.28$ and $1.72 \pm 0.23$ for the western and eastern Mediterranean, respectively; Roesler et al., 2017). Hence the bias correction factor of 2 was applied to BGC-Argo fluorescence data from both the Ligurian and Ionian regions, consistent with the processing performed at the Coriolis Data Center.

For the particulate backscattering coefficient $\left(b_{\mathrm{bp}}\right)$, we followed the BGC-Argo calibration and quality control procedure of Schmechtig et al. (2016). The backscattering coefficient at $700 \mathrm{~nm}\left(\mathrm{~m}^{-1}\right)$ is retrieved following Eq. (1):

$b_{\mathrm{bp}}(700)=2 \pi \chi\left[\left(\beta b_{\mathrm{bp}}-\right.\right.$ Dark $\left.b_{\mathrm{bp}}\right) \times$ Scale $\left.b_{\mathrm{bp}}-\beta \mathrm{sw}\right]$,

where $\chi=1.076$ is the empirical weighting function that converts the particulate volume scattering function at $124^{\circ}$ to the total backscattering coefficient (Sullivan et al., 2013), $\beta b_{\mathrm{bp}}$ is the raw observations from the backscattering meter (digital counts), Dark $b_{\mathrm{bp}}$ (digital counts) and Scale $b_{\mathrm{bp}}$ $\left(\mathrm{m}^{-1} \mathrm{sr}^{-1}\right.$ per count $)$ are the calibration coefficients provided by the manufacturer, and $\beta$ sw is the contribution to the volume scattering function (VSF) by the pure seawater at the $700 \mathrm{~nm}$ measurement wavelength that is a function of temperature and salinity (Zhang et al., 2009).

The calibration procedure applied to the particulate beam attenuation coefficient $\left(c_{\mathrm{p}}\right)$ is similar to that described in Mignot et al. (2014). The beam transmission $T(\%)$ is transformed into the beam attenuation coefficient $c\left(\mathrm{~m}^{-1}\right)$ using the following relationship:

$c=-\frac{1}{x} \ln \frac{T}{100}$,

where $x$ is the transmissometer pathlength $(25 \mathrm{~cm})$. The beam attenuation coefficient $c$ is the sum of the absorption and scattering by seawater and its particulate and dissolved constituents. At $660 \mathrm{~nm}$, the contribution of CDOM $\left(c_{\mathrm{CDOM}}\right)$ can be considered negligible in oligotrophic waters because, although its absorption in the blue is comparable to that of particulate material (Organelli et al., 2014), the $c_{\mathrm{CDOM}}$ spectrum decays exponentially towards nearly zero in the red (Bricaud et al., 1981), and because it is comprised of dissolved molecules and colloids, its scattering is negligible (Boss and Zaneveld, 2003). Meanwhile $c_{\mathrm{w}}$ (660) for pure water is constant and removed in the application of the factory calibration; effects due to dissolved salt are accounted for according to Zhang et al. (2009). Hence, at a wavelength of $660 \mathrm{~nm}$, the particle beam attenuation coefficient $c_{\mathrm{p}}\left(\mathrm{m}^{-1}\right)$ is retrieved by subtracting the seawater contribution to $c$. The biofouling-induced signal increase that is observed in clear deep waters and results in a drift in $c_{\mathrm{p}}$ values with time is corrected as follows. For each profile, a median $c_{\mathrm{p}}$ value, used as 
an "offset", is computed from the $c_{\mathrm{p}}$ values acquired between $300 \mathrm{~m}$ and the maximum sampled depth and subtracted from the entire profile.

Using the photosynthetically available radiation (PAR) measurements at solar noon, we computed the euphotic layer depth $\left(Z_{\text {eu }}\right)$ as the depth at which the PAR is reduced to $1 \%$ of its value just below the surface (Gordon and McCluney, $1975)$ and the penetration depth $\left(Z_{\mathrm{pd}}\right.$, also known as the efolding depth or first attenuation depth) as $Z_{\mathrm{eu}} / 4.6$. We define the surface layer from $0 \mathrm{~m}$ to $Z_{\mathrm{pd}}$. We also define the SCM layer as in Barbieux et al. (2019), whereby a Gaussian model is fit to each $\mathrm{Chl}$ vertical profile measured by the floats in order to determine the depth interval of the full width half maximum of the SCM. Finally, the mixed-layer depth (MLD) is derived from the float CTD data as the depth at which the potential density difference relative to the surface reference value is $0.03 \mathrm{~kg} \mathrm{~m}^{-3}$ (de Boyer Montégut et al., 2004).

Unlike the majority of BGC-Argo floats that collect profile measurements every $10 \mathrm{~d}$, the two platforms used in this study sampled the water column with four profiles every day, albeit with slightly different regimes (Fig. 2). The fLig float cycle commences with the first profile at sunrise $\left(t_{\mathrm{sr}}\right)$, a second at solar noon $\left(t_{\mathrm{n}}\right)$, a third profile at sunset the same day $\left(t_{\mathrm{ss}}\right)$ and a fourth profile at sunrise the next day $\left(t_{\mathrm{sr}+1}\right)$. The fLig float then acquires a profile at solar noon $4 \mathrm{~d}$ later $\left(t_{\mathrm{n}+4}\right)$, and then $3 \mathrm{~d}$ later restarts the acquisition of four profiles in $24 \mathrm{~h}$ from sunrise $\left(t_{\mathrm{sr}+7}\right)$. The fIon cycle is performed over a single $24 \mathrm{~h}$ period; it begins at sunrise $\left(t_{\mathrm{sr}}\right)$, followed by a second profile at solar noon $\left(t_{\mathrm{n}}\right)$, a third at sunset $\left(t_{\mathrm{ss}}\right)$ and a last night profile at approximately midnight $\left(t_{\mathrm{m}}\right)$. For this float, the sampling cycle is repeated each day.

\subsection{Characterization of the diel cycle of the bio-optical properties}

In order to characterize the amplitude and variability of the diel cycle of the $c_{\mathrm{p}}$ and $b_{\mathrm{bp}}$ coefficients, we use the metrics defined by Gernez et al. (2011) and Kheireddine and Antoine (2014). First, we compute the amplitude of the diurnal variation of the $c_{\mathrm{p}}$ and $b_{\mathrm{bp}}$ coefficients as

$$
\begin{aligned}
& \Delta c_{\mathrm{p}}=c_{\mathrm{p}}\left(t_{\mathrm{ss}}\right)-c_{\mathrm{p}}\left(t_{\mathrm{sr}}\right), \\
& \Delta b_{\mathrm{bp}}=b_{\mathrm{bp}}\left(t_{\mathrm{ss}}\right)-b_{\mathrm{bp}}\left(t_{\mathrm{sr}}\right),
\end{aligned}
$$

where $c_{\mathrm{p}}\left(t_{\mathrm{sr}}\right)$ and $b_{\mathrm{bp}}\left(t_{\mathrm{sr}}\right)$ are the values of $c_{\mathrm{p}}$ and $b_{\mathrm{bp}}$ at sunrise and $c_{\mathrm{p}}\left(t_{\mathrm{ss}}\right)$ and $b_{\mathrm{bp}}\left(t_{\mathrm{ss}}\right)$ are the values at sunset the same day.

We also consider the relative daily variation $\tilde{\Delta} c_{\mathrm{p}}$ and $\tilde{\Delta} b_{\mathrm{bp}}$ (expressed as percent change) for each float and each day of observation, from sunrise to sunrise as follows:

$$
\begin{aligned}
& \tilde{\Delta} c_{\mathrm{p}}=100\left(\frac{c_{\mathrm{p}}\left(t_{\mathrm{sr}}\right)}{c_{\mathrm{p}}\left(t_{\mathrm{sr}+1}\right)}-1\right), \\
& \tilde{\Delta} b_{\mathrm{bp}}=100\left(\frac{b_{\mathrm{bp}}\left(t_{\mathrm{sr}}\right)}{b_{\mathrm{bp}}\left(t_{\mathrm{sr}+1}\right)}-1\right),
\end{aligned}
$$

where $c_{\mathrm{p}}\left(t_{\mathrm{sr}}\right)$ and $b_{\mathrm{bp}}\left(t_{\mathrm{sr}}\right)$ are the values of $c_{\mathrm{p}}$ and $b_{\mathrm{bp}}$ at sunrise and $c_{\mathrm{p}}\left(t_{\mathrm{sr}+1}\right)$ and $b_{\mathrm{bp}}\left(t_{\mathrm{sr}+1}\right)$ are the values at sunrise the next day. Then the mean and range in relative daily variations $(m \tilde{\Delta}$ and $\tilde{r} \tilde{\Delta}$, respectively) are computed for each float over the entire time series.

\subsection{Principle of the bio-optical diel-cycle-based approach to biological production}

The two bio-optical properties that we considered in this study, $c_{\mathrm{p}}$ and $b_{\mathrm{bp}}$, are both linearly correlated to, and thus may be used as a proxy for, the stock of POC (e.g., Oubelkheir et al., 2005; Gardner et al., 2006; Cetinić et al., 2012). Both of these bio-optical proxies have been shown to exhibit a diurnal cycle (e.g., Oubelkheir and Sciandra, 2008; Loisel et al., 2011; Kheireddine and Antoine, 2014). The daily solar cycle is a major driver of biological activity in all oceanic euphotic zones, which influences the abundance of microorganisms, including phytoplankton (Jacquet et al., 1998; Vaulot and Marie, 1999; Brunet et al., 2007) and heterotrophic bacteria (Oubelkheir and Sciandra, 2008; Claustre et al., 2008), and, therefore, the magnitude of the $c_{\mathrm{p}}$ and $b_{\mathrm{bp}}$ coefficients. Diel changes in the $c_{\mathrm{p}}$ or $b_{\mathrm{bp}}$ coefficient reflect processes that affect the cellular abundance (number) and the attenuation (or backscattering) cross-section, which varies with cell size and the refractive index. The diurnal increase in $c_{\mathrm{p}}$ or $b_{\mathrm{bp}}$ has primarily been attributed to photosynthetic cellular organic carbon production (Siegel et al., 1998) that will first result in an increase in cell size or an increase in cell abundance and a decrease in cell size following cell division often occurring at night. In addition, the diurnal increase in $c_{\mathrm{p}}$ or $b_{\mathrm{bp}}$ may be caused by variations in cellular shape and the refractive index that accompany intracellular carbon accumulation (Stramski and Reynolds, 1993; Durand and Olson, 1996; Claustre et al., 2002; Durand et al., 2002). The nighttime decrease in $c_{\mathrm{p}}$ or $b_{\mathrm{bp}}$ may be explained by a decrease in cellular abundance due to aggregation, sinking or grazing (Cullen et al., 1992); a reduction in cell size; and/or a refractive index associated with cell division and respiration, the latter involving changes in intracellular carbon concentration with effect on the refractive index (Stramski and Reynolds, 1993). Community composition and cell physiology (in response to diel fluctuations of the light field) might also influence the optical diel variability through their effects on cell size and the refractive index. Diel variation in photoacclimation can be important in coastal communities dominated by microplankton (Litaker et al., 2002; Brunet et al., 2008). Nevertheless, previous studies 

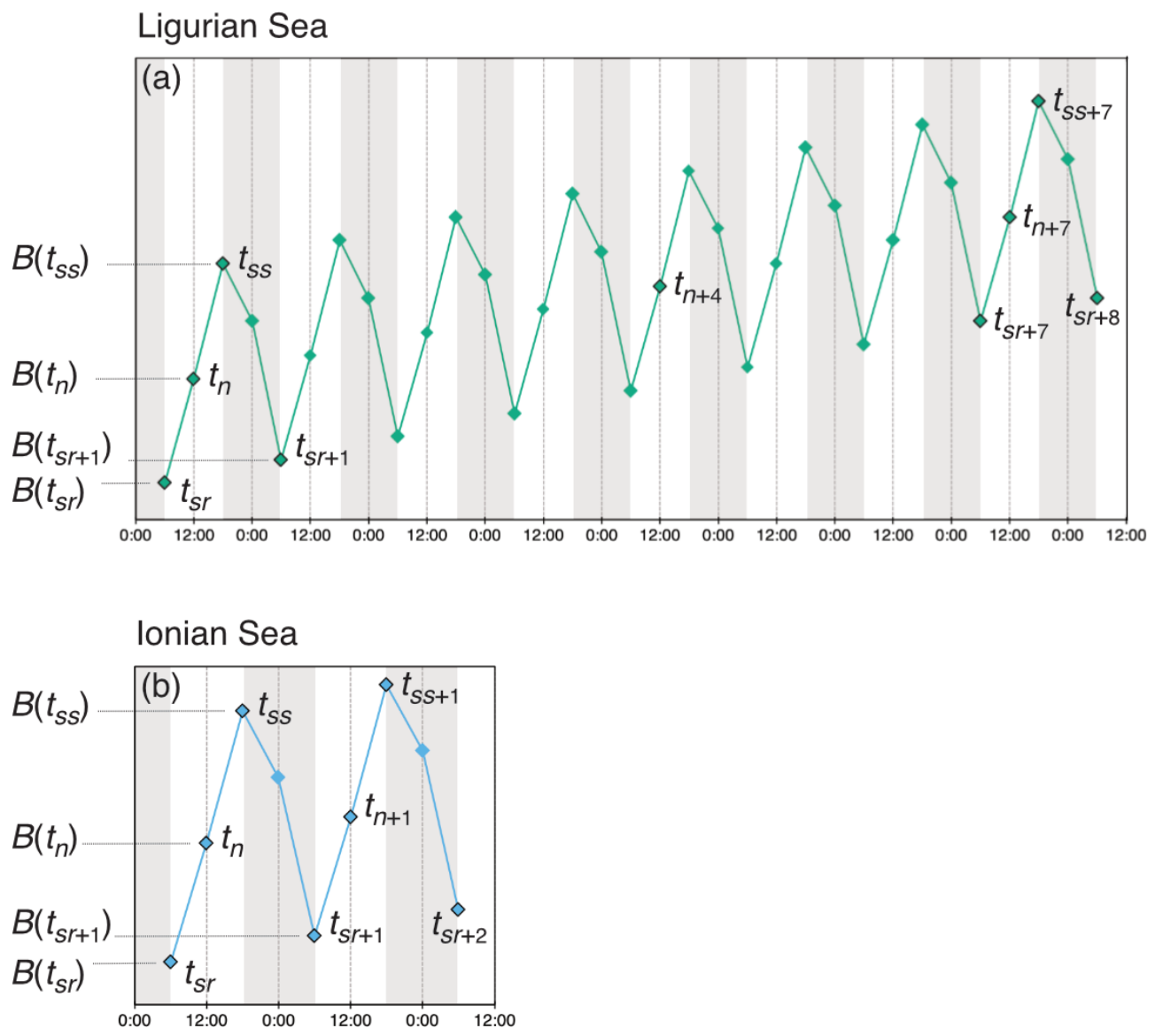

Figure 2. Schematic representation of the diel variations of the depth-integrated bio-optical properties converted to POC biomass $(B)$ and the sampling strategies employed in the (a) Ligurian Sea and (b) Ionian Sea. The diamond-shaped symbols indicate schematically the float profile times, labeled with timestamps associated with sunrise (sr), noon (n), sunset (ss) and midnight (m), with the corresponding POC biomass estimated within the considered layer (e.g., $\left.B\left(t_{\mathrm{sr}}\right)\right)$. The numeric subscripts $(+1,+2,+4$ or +5$)$ indicate the number of days since the first profile of the summertime time series.

conducted in oligotrophic environments suggest that photosynthetic growth is the major driver of the diurnal changes in $c_{\mathrm{p}}$ or $b_{\mathrm{bp}}$ (Gernez et al., 2002; Claustre et al., 2008). In addition, Claustre et al. (2002), in an experimental work based on Prochlorococcus, a frequent taxon in oligotrophic regions, show that although non-negligible, the diel variability in photoacclimation is much less pronounced than that in phytoplankton growth.

Following a modified version of Claustre et al. (2008), the observed daytime increase and nighttime decrease in $c_{\mathrm{p}^{-}}$derived (or $b_{\mathrm{bp}}$-derived) POC are used to estimate gross community production. For this purpose, the $c_{\mathrm{p}}$ and $b_{\mathrm{bp}}$ coefficients, measured in situ by the BGC-Argo profiling floats, are converted into POC equivalent using a constant $c_{\mathrm{p}}$-to-POC (or $b_{\mathrm{bp}}$-to-POC) relationship from the literature (see below). By definition, the $c_{\mathrm{p}}$ and $b_{\mathrm{bp}}$ coefficients target particles so that the dissolved biological matter is not accounted for by the present method.

\subsection{Bio-optical properties-to-POC relationships}

The conversion of $c_{\mathrm{p}}$ and $b_{\mathrm{bp}}$ into POC relies on the use of empirical proxy relationships and assumptions concerning the variations in those relationships. First, as in Claustre et al. (2008), we assume that the $c_{\mathrm{p}^{-}}$or $b_{\mathrm{bp}}$-to-POC relationship remains constant on a daily timescale, consistent with previous works (Stramski and Reynolds, 1993; Cullen and Lewis, 1995), so that observed variations in the optical coefficients can be interpreted as variations in POC. Second, the specific proxy value is not constant, as many empirical relationships between POC and $c_{\mathrm{p}}$ (e.g., Claustre et al., 1999; Oubelkheir et al., 2005; Gardner et al., 2006; Loisel et al., 2011) or $b_{\text {bp }}$ (e.g., Stramski et al., 2008; Loisel et al., 2011; Cetinić et al., 2012) have been proposed for specific regions (Tables 1 and 2). In the present study, we used the relationships from Oubelkheir et al. (2005) and Loisel et al. (2011) for $c_{\mathrm{p}}$ and $b_{\mathrm{bp}}$, respectively. Both relationships were established from in situ measurements collected in the Mediterranean Sea and produce $c_{\mathrm{p}}$ - or $b_{\mathrm{bp}}$-derived POC values falling in the middle 
of the range of all the POC values resulting from the different bio-optical relationships taken from the literature (Tables 1 and 2).

\subsection{Estimating biological production from the diel cycle of POC}

\subsubsection{Hypotheses}

The time rate of change in depth-resolved POC biomass $b(z, t)$ can be described by a partial differential equation:

$\frac{\partial b(z, t)}{\partial t}=\mu(z, t) b(z, t)-l(z, t) b(z, t)$,

where $\mu(z, t)$ is the particle photosynthetic growth rate and $l(z, t)$ is the particle loss rate at depth $z$ and time $t$ (both in units of $d^{-1}$ ). As in previous studies (Claustre et al., 2008; Gernez et al., 2011; Barnes and Antoine, 2014), we assume a 1D framework. In other words, we ignore the effects of lateral transport of particles by oceanic currents and assume that there is no vertical transport of particles into or out of the layer considered. We also assume that the loss rate is constant throughout the day and uniform with depth, i.e., $l(z, t)=l$. In this context, the time series of profiles are first converted to depth-integrated biomass (from $b(z, t)$ to $B(t)$ ) for each of the layers in question and then integrated over time to determine daytime gain, nighttime loss and net daily production.

\subsubsection{Calculation of the loss rate}

During nighttime, there is no photosynthetic growth so that Eq. (5) becomes

$\frac{\partial b(z, t)}{\partial t}=l b(z, t)$.

The integration of Eq. (6) over depth yields an expression of the rate of change of the depth-integrated POC biomass $B(t)$ :

$\frac{\partial B(t)}{\partial t}=-l B(t)$,

where $B(t)=\int_{z_{2}}^{z_{1}} b(z, t) \mathrm{d} z$, the POC integrated within a given layer of the water column, is comprised between the depths $z_{1}$ and $z_{2}$ (in $\mathrm{gC} \mathrm{m}^{-2}$ ). In this respect, we consider three different layers: the euphotic layer extending from $z_{1}=0 \mathrm{~m}$ to $z_{2}=Z_{\text {eu }}$; the surface layer extending from $z_{1}=$ $0 \mathrm{~m}$ to $z_{2}=Z_{\mathrm{pd}}$; and the SCM layer extending from $z_{1}=$ $Z_{\mathrm{SCM}}-Z_{\mathrm{SCM}, 1 / 2}$ and $z_{2}=Z_{\mathrm{SCM}}+Z_{\mathrm{SCM}, 1 / 2}$, where $Z_{\mathrm{SCM}}$ is the depth of the SCM and $Z_{\mathrm{SCM}, 1 / 2}$ is the depth at which $\mathrm{Chl}$ is half of the SCM value.

Equation (7) can be integrated over nighttime to obtain an equation for the loss rate $l$, as a function of the nocturnal variation of $B$ :

$l=\frac{\ln \left(\frac{B_{\mathrm{ss}}}{B_{\mathrm{sr}+1}}\right)}{t_{\mathrm{sr}+1}-t_{\mathrm{ss}}}$, where $B\left(t_{\mathrm{ss}}\right)$ and $B\left(t_{\mathrm{sr}+1}\right)$ correspond to the POC integrated within the layer of interest, at $t_{\mathrm{ss}}$ (sunset) and $t_{\mathrm{sr}+1}$ (sunrise of the next day).

\subsubsection{Calculation of the production rate}

The daily $(24 \mathrm{~h})$ depth-integrated gross production of POC $P$ (in units of $\mathrm{gC} \mathrm{m}^{-2} \mathrm{~d}^{-1}$ ) is defined as

$P=\int_{t_{\mathrm{sr}}}^{t_{\mathrm{sr}+1}} \int_{z_{2}}^{z_{1}} \mu(z, t) b(z, t) \mathrm{d} z, \mathrm{~d} t$

where $t_{\mathrm{sr}}$ is the time of sunrise on day 1 and $t_{\mathrm{sr}+1}$ is the time of sunrise the following day. Equation (5) can be used to express $P$ as a function of $l, b(z, t)$ and the rate of change of $b(z, t)$ :

$P=\int_{t_{\mathrm{sr}}}^{t_{\mathrm{sr}+1}} \int_{z_{2}}^{z_{1}}\left(\frac{\partial b(z, t)}{\partial t}+l b(z, t)\right) \mathrm{d} z \mathrm{~d} t$,

which yields

$P=B_{t_{\mathrm{sr}+1}}-B_{t_{\mathrm{sr}}}+l \int_{t_{\mathrm{sr}}}^{t_{\mathrm{sr}+1}} B(t) \mathrm{d} t$,

where the gross production $P$ is calculated as the sum of the net daily changes in POC biomass plus POC losses, assuming a constant rate $(l)$ during daytime and nighttime.

Finally, using the trapezoidal rule, Eq. (11) simplifies into

$P=B_{t_{\mathrm{sr}+1}}-B_{t_{\mathrm{sr}}}+l \sum_{i=1}^{j}\left(t_{i+1}-t_{i}\right) \frac{B_{i+1}+B_{i}}{2}$,

where $l$ is calculated from Eq. (8) and the index $i$ corresponds to the different measurement time steps over the course of the diel cycle $\left(t_{\mathrm{sr}}, t_{\mathrm{n}}, t_{\mathrm{ss}}\right.$ and $t_{\mathrm{sr}+1} ;$ Fig. 2).

In summary, Eq. (12) is applied to the time series of the BGC-Argo floats by using $b_{\mathrm{bp}}$ and $c_{\mathrm{p}}$ converted into POC equivalents, integrated within the euphotic, surface and SCM layers to compute $c_{\mathrm{p}^{-}}$and $b_{\mathrm{bp}}$-derived estimates of gross community production $P$ in all three layers of the water column.

\subsection{Primary production model}

The community production estimates obtained from the biooptical diel-cycle-based method are evaluated against primary production values computed with the bio-optical primary production model of Morel (1991). Morel's model estimates the daily depth-resolved organic carbon concentration fixed by photosynthesis, using the noontime measurements of Chl, temperature and PAR within the water column by the BGC-Argo profiling floats as model inputs. The standard phytoplankton photophysiological parameterization is used for these calculations (Morel, 1991; Morel et al., 1996). 
Table 1. POC-to- $c_{\mathrm{p}}$ relationships from the literature (with POC and $c_{\mathrm{p}}$ in units of $\mathrm{mg} \mathrm{m}^{-3}$ and $\mathrm{m}^{-1}$, respectively).

\begin{tabular}{lll}
\hline Reference & Region & Relationship \\
\hline Marra et al. (1995) & North Atlantic & POC $=367 c_{\mathrm{p}}(660)+31.2$ \\
Claustre et al. (1999) & Equatorial Pacific & POC $=501.81 c_{\mathrm{p}}(660)+5.33$ \\
Oubelkheir et al. (2005) & Mediterranean & POC $=574 c_{\mathrm{p}}(555)-7.4$ \\
Behrenfeld and Boss (2006) & Equatorial Pacific & POC $=585.2 c_{\mathrm{p}}(660)+7.6$ \\
Gardner et al. (2006) & Global ocean & POC $=381 c_{\mathrm{p}}(660)+9.4$ \\
Stramski et al. (2008) & Pacific and Atlantic, including upwelling & POC $=661.9 c_{\mathrm{p}}(660)-2.168$ \\
Loisel et al. (2011) & Mediterranean & POC $=404 c_{\mathrm{p}}(660)+29.25$ \\
Cetinić et al. (2012) & North Atlantic & POC $=391 c_{\mathrm{p}}(660)-5.8$ \\
\hline
\end{tabular}

Table 2. POC-to- $b_{\mathrm{bp}}$ relationships from the literature (with POC and $b_{\mathrm{bp}}$ in units of $\mathrm{mg} \mathrm{m}^{-3}$ and $\mathrm{m}^{-1}$, respectively).

\begin{tabular}{lll}
\hline Reference & Region & Relationship \\
\hline Stramski et al. (2008) & $\begin{array}{l}\text { Pacific and Atlantic, } \\
\text { including upwelling }\end{array}$ & POC $=71002 b_{\mathrm{bp}}(555)-5.5$ \\
Loisel et al. (2011) & Mediterranean & $\mathrm{POC}=37550 b_{\mathrm{bp}}(555)+1.3$ \\
Cetinić et al. (2012) & North Atlantic & POC $=35422 b_{\mathrm{bp}}(700)-14.4$ \\
\hline
\end{tabular}

\subsection{Phytoplankton pigments and community composition}

During the BOUSSOLE cruises conducted in 2014 (cruises 143 to 154 ) and the PEACETIME cruise, discrete seawater samples were taken at 10-12 depths within the water column from Niskin bottles mounted on a CTD rosette system and then filtered under low vacuum onto Whatman $\mathrm{GF} / \mathrm{F}$ filters $(0.7 \mu \mathrm{m}$ nominal pore size, $25 \mathrm{~mm}$ diameter $)$. The filters were flash-frozen in liquid nitrogen and stored at $-80^{\circ} \mathrm{C}$ until analysis by HPLC following the protocol of Ras et al. (2008). The concentrations of phytoplankton pigments resulting from these analyses were used to estimate the composition of the phytoplankton assemblage. For this purpose, we used the diagnostic pigment-based approach (Claustre, 1994; Vidussi et al., 2001; Uitz et al., 2006) with the coefficients of Di Cicco et al. (2017) to account for the specificities of Mediterranean phytoplankton communities. This approach yields the relative contribution to chlorophyll $a$ biomass of major taxonomic groups merged into three size classes (micro-, nano- and picophytoplankton).

The fLig float was spatially distanced from the location of sampling at the BOUSSOLE mooring site. Thus, it was necessary to identify the time shift for matching the cruisesampled analyses to the float profile measurements. This was achieved by performing a cross-correlation analysis of the bio-optical time series measurements collected on the float with that on the mooring (in this case Chl, $c_{\mathrm{p}}$ and $b_{\mathrm{bp}}$ ). A positive time lag between the BOUSSOLE site and the position of the fLig float during its drift is observed, suggesting that the variations observed by the float led that observed at BOUSSOLE by $\sim 2 \mathrm{~d}$. This small time lag, cou- pled with high correlation coefficient values and long decorrelation timescales, indicates that the monthly interpolated pigment data measured at the BOUSSOLE site may be considered representative of the pigment composition along the fLig float trajectory.

\section{Results and discussion}

We first provide an overview of the biogeochemical and biooptical characteristics measured by the two BGC-Argo profiling floats in the Ligurian and Ionian seas. We then assess the usefulness of the diel cycle of the $b_{\mathrm{bp}}$ coefficient for deriving community production, in comparison to the $c_{\mathrm{p}}$ derived estimates as a reference, and discuss the $c_{\mathrm{p}}$-derived estimates. Finally, we examine the community production estimates in both study regions, with an emphasis on the SCM layer and its biogeochemical significance.

\subsection{Biogeochemical and bio-optical context in the study regions}

Both study regions are characterized by either seasonal or persistent oligotrophy, with mean surface Chl values ranging within $0.08-0.22 \mathrm{mg} \mathrm{m}^{-3}$ (Fig. 3) and a stratified water column with a consistently shallow MLD $(<30 \mathrm{~m})$. They do exhibit very different euphotic depths, with a mean $Z_{\mathrm{eu}}$ of $47 \pm 5$ and $89 \pm 4 \mathrm{~m}$ in the Ligurian and Ionian seas, respectively. Consistently, the instantaneous midday PAR values are much lower in the upper layer of the Ligurian Sea $\left(93 \pm 70 \mu \mathrm{E} \mathrm{m}^{-2} \mathrm{~s}^{-1}\right.$; einstein per square meter per second) than in the Ionian Sea $\left(500 \pm 60 \mu \mathrm{E} \mathrm{m}^{-2} \mathrm{~s}^{-1}\right)$ and shows a more rapid decrease within the water column as phy- 
toplankton biomass absorbs light. Both regions also display an SCM, the depth of which co-occurs with $Z_{\text {eu }}$ and the isopycnal 28.85 (i.e., the isoline of potential density at $28.85 \mathrm{~kg} \mathrm{~m}^{-3}$ ) over the considered time series, except for the last month of observation in the Ionian Sea.

In the Ligurian Sea, the SCM is intense $\left(1.06 \pm 0.34 \mathrm{mg} \mathrm{Chl} \mathrm{m}^{-3}\right.$; Fig. 3a), relatively shallow $(41 \pm 7 \mathrm{~m})$, and associated with the subsurface $c_{\mathrm{p}}$ and $b_{\text {bp }}$ maxima $\left(0.27 \pm 0.09\right.$ and $0.0015 \pm 0.0006 \mathrm{~m}^{-1}$, respectively; Fig. $3 \mathrm{~b}-\mathrm{c})$. The $\mathrm{Chl}$ and $c_{\mathrm{p}}$ values are 5 times larger in the SCM layer than at the surface, and the $b_{\mathrm{bp}}$ values are 3.6 times larger. In contrast, in the Ionian Sea, the SCM is associated with lower values of $\mathrm{Chl}$ $\left(0.27 \pm 0.07 \mathrm{mg} \mathrm{m}^{-3} ;\right.$ Fig. $\left.3 \mathrm{~d}\right), c_{\mathrm{p}}\left(0.05 \pm 0.01 \mathrm{~m}^{-1} ;\right.$ Fig. $\left.3 \mathrm{e}\right)$ and $b_{\mathrm{bp}}\left(0.0005 \pm 0.0001 \mathrm{~m}^{-1}\right.$; Fig. 3f). Compared to the Ligurian Sea SCM, the Ionian Sea SCM is located twice as deep $(97 \pm 11 \mathrm{~m})$ and is uncoupled from the $c_{\mathrm{p}}$ and $b_{\mathrm{bp}}$ maxima that occur at a shallower depth.

Hence, the selected regions are representative of two contrasted SCM systems with distinct degrees of oligotrophy, consistent with our expectations (e.g., D'Ortenzio and Ribera D'Alcalà, 2009; Barbieux et al., 2019). Such a contrast in the SCM characteristics in relation to the trophic gradient of the environment has already been observed in the Mediterranean Sea (e.g., Lavigne et al., 2015; Barbieux et al., 2019) and on a global scale (e.g., Cullen, 2015, and references therein; Mignot et al., 2014; Cornec et al., 2021). These studies report that the depth of the SCM is inversely correlated with the surface $\mathrm{Chl}$ (an index of the trophic status) and light attenuation within the water column. Previous studies (Mignot et al., 2014; Barbieux et al., 2019; Cornec et al., 2021) indicate that moderately oligotrophic, temperate conditions are generally associated with a relatively shallow SCM coupled to a maximum in $c_{\mathrm{p}}$ or $b_{\mathrm{bp}}$, reflecting an increase in phytoplankton carbon biomass (SBM). In contrast, in the most oligotrophic environments, the vertical distribution of $\mathrm{Chl}$ shows a maximum at greater depths and is decoupled from the $c_{\mathrm{p}}$ or $b_{\mathrm{bp}}$ vertical distribution. Furthermore, Barbieux et al. (2019) show that, in the northwestern Mediterranean region, the SCM mirrors a biomass maximum located slightly above $Z_{\mathrm{eu}}$, which benefits from an adequate light-nutrient regime thanks to a deep winter convective mixing allowing for nutrient replenishment in the upper ocean. In the Ionian Sea where the MLD and nutricline are permanently decoupled, the SCM establishes below $Z_{\mathrm{eu}}$ as phytoplankton organisms attempt to reach nutrient resources. Prevailing low-light conditions lead to the pronounced photoadaptation of phytoplankton. Thus, consistent with previous work, the present observations indicate that the Ligurian Sea SCM is a phytoplankton carbon biomass (SBM) likely resulting from favorable light and nutrient conditions, whereas the Ionian SCM would be essentially induced by photoacclimation of phytoplankton cells.

Although the summer period is typically considered stable, some temporal variations are observed over the time se- ries that are more pronounced in the SCM layer than at the surface. In the Ligurian Sea SCM, Chl, $c_{\mathrm{p}}$ and $b_{\mathrm{bp}}$ values exhibit similar temporal evolution, with relatively high values in late May 2014, followed by a marked decrease until midJuly (Fig. 4a-c). Then we observe two local minima in Chl, $c_{\mathrm{p}}$ and $b_{\mathrm{bp}}$ that delineate a second peak between 14 July and 16 August 2014 (as indicated by the dashed lines in Fig. 4ac). In the Ionian Sea SCM, Chl, $c_{\mathrm{p}}$ and $b_{\mathrm{bp}}$ values all decrease from late May until a minimum is reached on 11 August 2017 (dashed line in Fig. 4d-e), and a second increase is recorded later in the season. These temporal patterns are further discussed in relation to the variability in the estimated POC and production rates (Sect. 3.4).

\subsection{Assessment of the method}

\subsubsection{Analysis of the diel cycle of the $c_{\mathrm{p}}$ and $b_{\mathrm{bp}}$ coefficients}

Diel cycles, characterized by a daytime increase and a nighttime decrease, are observed in both $c_{\mathrm{p}}$ and $b_{\mathrm{bp}}$ time series in all layers of the water column, as illustrated for the SCM layer of the Ionian Sea in Fig. 5 (examples of the diel cycles of $c_{\mathrm{p}}$ and $b_{\mathrm{bp}}$ for both the Ligurian and Ionian seas are provided in Appendix A). Considering the time series of the Ligurian and Ionian seas, as well as the surface and SCM layers, the $c_{\mathrm{p}}$ and $b_{\mathrm{bp}}$ coefficients show mean diurnal amplitudes, $\Delta c_{\mathrm{p}}$ and $\Delta b_{\mathrm{bp}}$, spanning between 0.001 and $0.02 \mathrm{~m}^{-1}$ and $7 \times 10^{-6}$ and $9 \times 10^{-5} \mathrm{~m}^{-1}$, respectively. These results are consistent with Gernez et al. (2011), who observed $\Delta c_{\mathrm{p}}$ values ranging within 0.01 and $0.07 \mathrm{~m}^{-1}$ in the surface layer of the Ligurian Sea (BOUSSOLE mooring) during the summer to fall oligotrophic period. Relative to the mean $c_{\mathrm{p}}$ and $b_{\mathrm{bp}}$ values, the mean $\Delta c_{\mathrm{p}}$ and $\Delta b_{\mathrm{bp}}$ correspond to diurnal variations of $9 \%-20 \%$ and $5 \%-10 \%$, respectively.

In the surface layer of the Ligurian Sea, the diel cycles of $c_{\mathrm{p}}$ and $b_{\mathrm{bp}}$ exhibit, respectively, mean relative daily variation $(\tilde{m \Delta})$ of $12.7 \%$ and $2.3 \%$ and a range in relative daily variations $(r \tilde{\Delta})$ of $256.7 \%$ and $28.5 \%$ (Table 3 ). These values are of the same order of magnitude as those reported by Kheireddine and Antoine (2014), acquired from the BOUSSOLE surface mooring in the same area and during the oligotrophic season (from $-5 \%$ to $25 \%$ for $c_{\mathrm{p}}$ and from $-2 \%$ to $10 \%$ for $\left.b_{\mathrm{bp}}\right)$. Interestingly, the diel cycle of the $c_{\mathrm{p}}$ coefficient appears systematically more pronounced than that of $b_{\mathrm{bp}}$, with larger values of $\tilde{m \Delta}$ and $\tilde{r}$, regardless of the considered region and layer of the water column (Table 3 ).

To first order, the variability in the $b_{\mathrm{bp}}$ and $c_{\mathrm{p}}$ coefficients is determined by the variability in particle concentration, which underpins their robustness as POC proxies in openocean conditions and explains their coherent evolution on a monthly timescale (Figs. 3-4). Nevertheless, to second order, these coefficients vary differentially with the size and composition of the particle pool. In particular, phytoplankton make a larger contribution to $c_{\mathrm{p}}$ than $b_{\mathrm{bp}}$, in part due to their 


\section{Ligurian Sea}
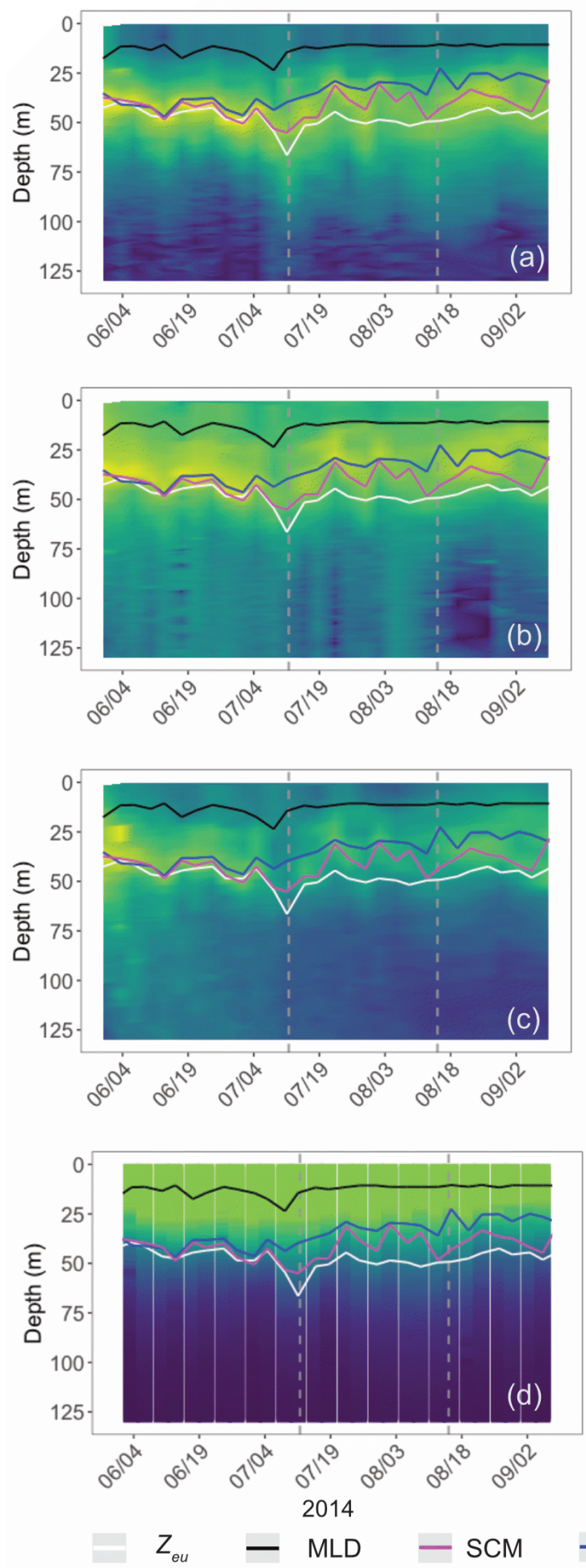

Ionian Sea
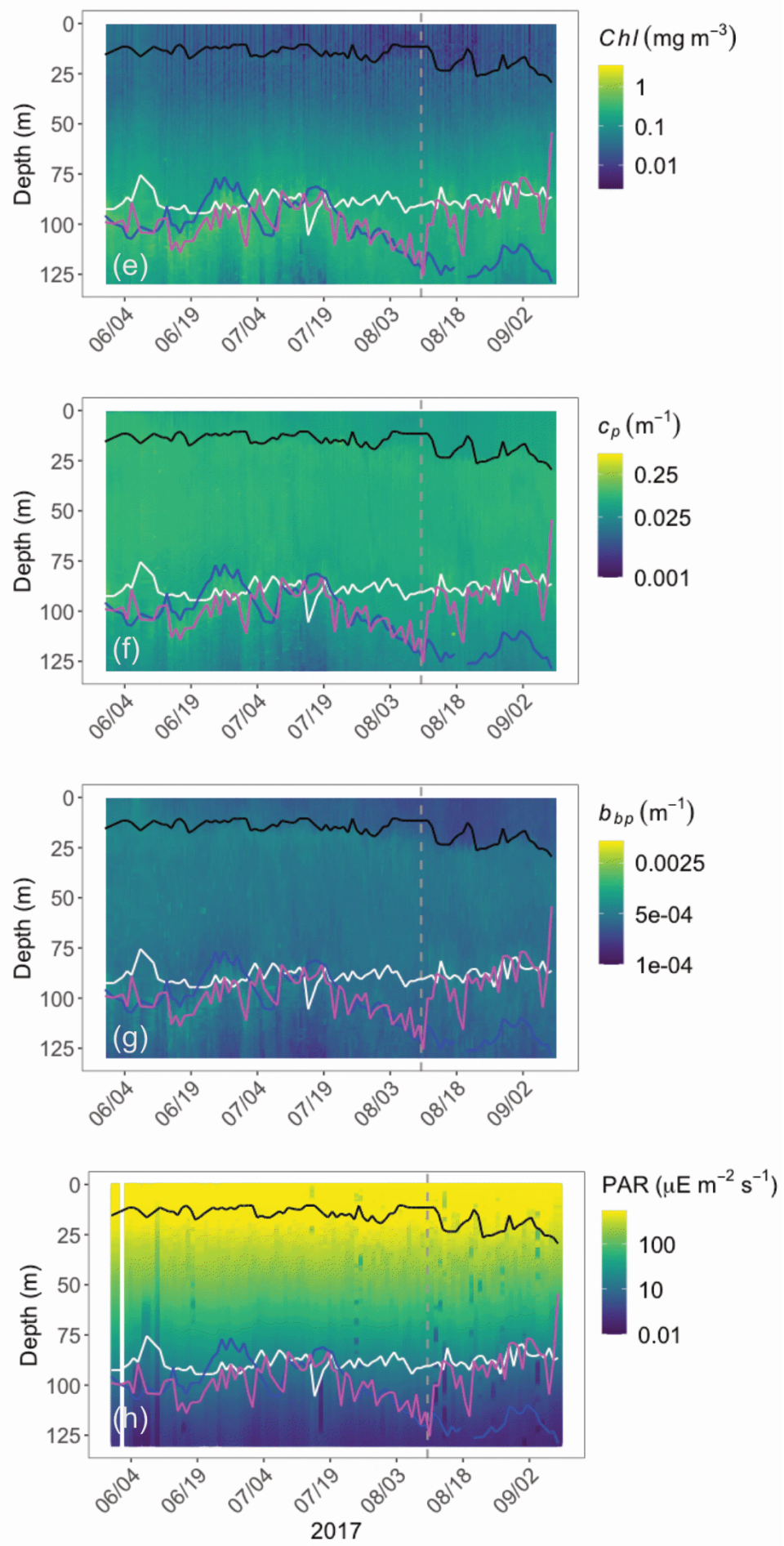

- Isopycnal 28.85

Figure 3. Time series of the vertical distribution of the $\mathrm{Chl}(\mathbf{a}, \mathbf{d}), b_{\mathrm{bp}}(\mathbf{b}, \mathbf{e}), c_{\mathrm{p}}(\mathbf{d}, \mathbf{f})$ and instantaneous midday PAR (d, h), in the Ligurian Sea (a-d) and the Ionian Sea (e-h). The euphotic depth $\left(Z_{\text {eu }}\right.$; white line), the mixed-layer depth (MLD; black line), the depth of the SCM (magenta line) and the depth of the isopycnal 28.85 expressed as $\sigma_{\mathrm{t}}$ (blue line) are superimposed onto the bio-optical time series. The dashed lines indicate the dates at which the $c_{\mathrm{p}}$ and the $b_{\mathrm{bp}}$ values in the SCM layer reach a minimum. Please note that the date format in this figure is month/day. 

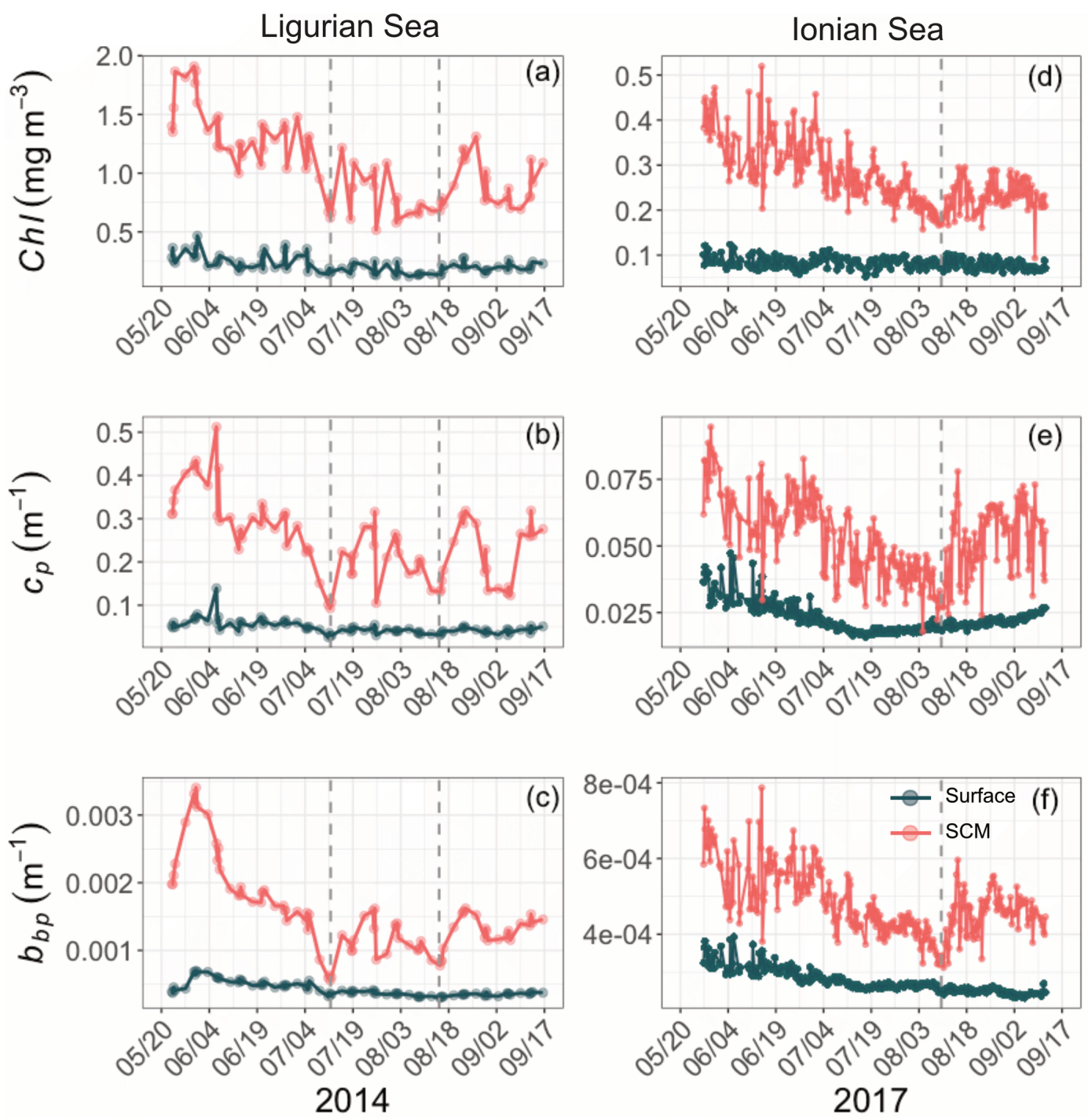

Figure 4. Temporal evolution of $\mathrm{Chl}(\mathbf{a}, \mathbf{d}), c_{\mathrm{p}}(\mathbf{b}, \mathbf{e})$ and $b_{\mathrm{bp}}(\mathbf{c}, \mathbf{f})$ in the surface (dark green) and SCM (red) layers for the Ligurian Sea (a-c) and the Ionian Sea (d-f). The dashed lines indicate the dates when the values of $c_{\mathrm{p}}$ and $b_{\mathrm{bp}}$ in the SCM layer reach a minimum. Please note that the date format in this figure is month/day.

Table 3. Mean and range $(\%)$ in relative daily variations $(\tilde{m \Delta}$ and $\tilde{r \Delta}$, respectively) in the diel cycle of $c_{\mathrm{p}}$ and $b_{\mathrm{bp}}$ computed for each float over the entire time series, for the two considered regions and in the surface $\left(0-Z_{\mathrm{pd}}\right)$ and SCM layers of the water column.

\begin{tabular}{llrr|rr}
\hline & & \multicolumn{2}{c|}{ Surface layer } & \multicolumn{2}{c}{ SCM layer } \\
\cline { 2 - 6 } Region & & $\tilde{\Delta} c_{\mathrm{p}}$ & $\tilde{\Delta} b_{\mathrm{bp}}$ & $\tilde{\Delta} c_{\mathrm{p}}$ & $\tilde{\Delta} b_{\mathrm{bp}}$ \\
\hline \multirow{2}{*}{ Ligurian Sea } & $\tilde{m \Delta}$ & 12.7 & -2.3 & 14.5 & 3.8 \\
& $\tilde{r \Delta}$ & 256.7 & 28.5 & 194.8 & 107.8 \\
\hline \multirow{2}{*}{ Ionian Sea } & $\tilde{m} \Delta$ & 0.55 & 0.23 & 1.16 & 0.06 \\
& $\tilde{r \Delta}$ & 54.4 & 21.2 & 102.4 & 57.3 \\
\hline
\end{tabular}

strong absorption efficiency. In addition, $b_{\mathrm{bp}}$ is more sensitive to smaller $(<1 \mu \mathrm{m})$ particles (Stramski and Kiefer, 1991; Ahn et al., 1992; Stramski et al., 2001; Boss et al., 2004) and to particle shape and internal structure (Bernard et al., 2009; Neukermans et al., 2012; Moutier et al., 2017; Organelli et al., 2018). While the diel cycle of $c_{\mathrm{p}}$ would be essentially driven by photosynthetic processes due to the influence of phytoplankton on $c_{\mathrm{p}}, b_{\mathrm{bp}}$ would be more responsive to detritus and/or heterotrophic bacteria that show minor, if not negligible, daily variability. Hence, such specificities in the bio-optical coefficients may explain the observed differences in their diel cycles.

Based on high-frequency surface measurements in the Ligurian Sea in various seasons, the studies of Kheireddine and Antoine (2014) and Barnes and Antoine (2014) demon- 


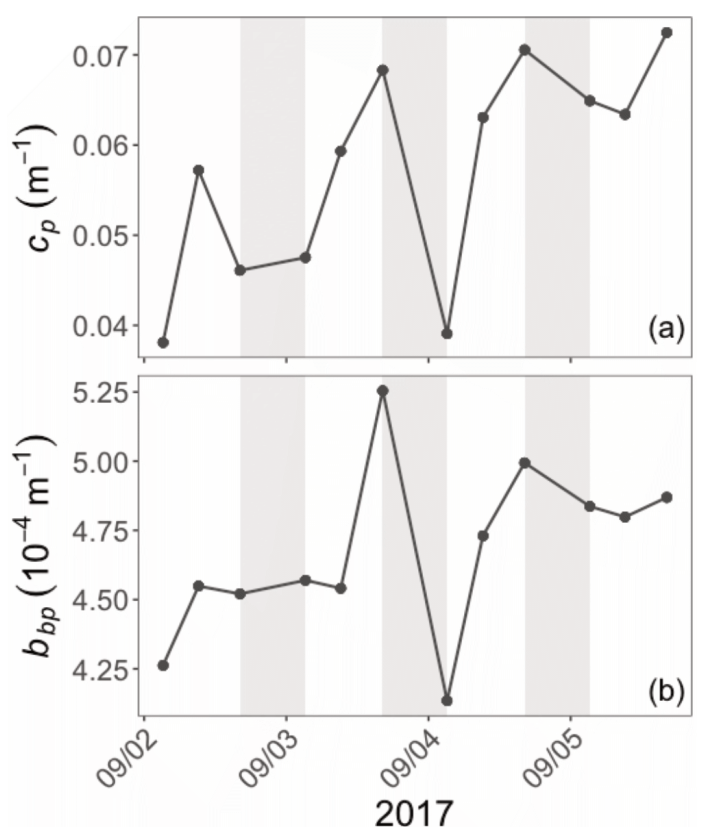

Figure 5. Example of the variations of the $c_{\mathrm{p}}$ (a) and $b_{\mathrm{bp}}$ (b) coefficients at the daily timescale in the Ionian Sea in the SCM layer during the interval from 2 to 6 September 2017. The grey-shaded area indicates the nighttime. Please note that the date format in this figure is month/day.

strated that not only does the diel cycle of $b_{\mathrm{bp}}$ exhibit much reduced relative amplitude compared to that of $c_{\mathrm{p}}$ but also the features of the $b_{\mathrm{bp}}$ cycle are not synchronous with that of the $c_{\mathrm{p}}$ cycle. Thus, $b_{\mathrm{bp}}$ cannot be used interchangeably with $c_{\mathrm{p}}$ for assessing daily changes in POC or community production but perhaps provides additional information on the particulate matter and its production rates. Our results support these previous findings, not only for the surface layer of the Ligurian Sea but also for the whole water column of both the Ligurian and Ionian regions.

We now consider the integrated euphotic-zone gross community production estimates derived from the bio-optical diel-cycle-based method (Fig. 6). We compare the $c_{\mathrm{p}^{-}}$and $b_{\text {bp }}$-based estimates with primary production estimates computed with the model of Morel (1991). The $b_{\mathrm{bp}}$-derived production rates underestimate those derived from $c_{\mathrm{p}}$ in both regions by about a factor of 10 , with respective mean values of $0.11 \pm 0.28$ and $1.18 \pm 1.13 \mathrm{gC} \mathrm{m}^{-2} \mathrm{~d}^{-1}$ in the Ligurian Sea and $0.04 \pm 0.04$ and $0.46 \pm 0.11 \mathrm{gC} \mathrm{m}^{-2} \mathrm{~d}^{-1}$ in the Ionian Sea. In addition, the $b_{\mathrm{bp}}$-derived production is much lower than the primary production computed with the model of Morel (1991), which has mean values of $0.91 \pm 0.14 \mathrm{gC} \mathrm{m}^{-2} \mathrm{~d}^{-1}$ in the Ligurian Sea and $0.31 \pm 0.04 \mathrm{gC} \mathrm{m}^{-2} \mathrm{~d}^{-1}$ in the Ionian Sea. The significantly lower community production rates are a direct effect of the dampened relative daily amplitude of the $b_{\mathrm{bp}}$ diel cycle (Table 3 ) and the sensitivity of $b_{\mathrm{bp}}$ to the smaller heterotrophic and detrital particulate matter. The bio-optical diel-cycle-based method, whether applied to $c_{\mathrm{p}}$ or $b_{\mathrm{bp}}$, yields an estimate of the community production, i.e., that associated with the accumulation of phytoplankton and bacteria biomass, which is necessarily larger than the primary (photoautotrophic) production rates from the Morel (1991) model. These questionable low values of community production, along with the observation of a weak daily variability in $b_{\mathrm{bp}}$, support the idea that the diel cycle of $b_{\mathrm{bp}}$ may not be a reliable index for total community production rates, consistent with previous studies (Kheireddine and Antoine, 2014; Barnes and Antoine, 2014). However, the utility of a $b_{\mathrm{bp}^{-}}$ derived community production may be revealed in elucidating rates for distinct size-based groups of organisms, such as picoplankton. A better understanding of the specific size range that dominates the diel cycle in $b_{\mathrm{bp}}$ will be important to understand. Yet, for our purposes, we disregard the $b_{\mathrm{bp}}$-based estimates and focus our analysis on the $c_{\mathrm{p}}$-derived gross community production estimates.

\subsubsection{Community production derived from the $c_{\mathrm{p}}$ coefficient}

The $c_{\mathrm{p}}$-derived estimates of gross community production, integrated within the euphotic layer, compare favorably with those found in the literature for similar Mediterranean areas (see Table 4 and references therein). The $c_{\mathrm{p}}$-based estimates show a 2.5-fold difference between the Ligurian Sea and the Ionian Sea (mean of 1.18 and $0.46 \mathrm{gC} \mathrm{m}^{-2} \mathrm{~d}^{-1}$, respectively; Table 6). In comparison, water-column-integrated primary production values, either inferred from satellite observations and biogeochemical models or measured in situ, vary within the range of $0.13-1$ to $0.14-0.69 \mathrm{gC} \mathrm{m}^{-2} \mathrm{~d}^{-1}$ for the western (or Ligurian) and eastern (or Ionian) region, respectively (Table 4). As expected, our $c_{\mathrm{p}}$-based community production rates are larger than published primary production rates. The present $c_{\mathrm{p}}$-derived values also compare favorably with gross community production estimates inferred from a similar approach applied to bio-optical measurements from the BOUSSOLE mooring in the Ligurian Sea $\left(0.5-0.8 \mathrm{gC} \mathrm{m}^{-2} \mathrm{~d}^{-1}\right.$ in Gernez et al., 2011; 0.8-1.5 $\mathrm{gC} \mathrm{m}^{-2} \mathrm{~d}^{-1}$ in Barnes and Antoine, 2014) and along an oligotrophic gradient in the subtropical South Pacific Ocean $\left(0.85 \mathrm{gC} \mathrm{m}^{-2} \mathrm{~d}^{-1}\right.$; Claustre et al., 2008).

The empirical relationships linking the $c_{\mathrm{p}}$ (or $b_{\mathrm{bp}}$ ) coefficient to POC are known to exhibit regional and seasonal variability in response to changes in the composition of the particle assemblage and associated changes in particle size, shape and type, i.e., biogenic or mineral (e.g., Stramski et al., 2004; Neukermans et al., 2012; Slade and Boss, 2015). Hence, the choice of such relationships strongly affects the conversion of the measured daily bio-optical variability into POC fluxes. For the time period and study regions here, the $c_{\mathrm{p}}$-based community production varies by a factor of 2, depending on the selected bio-optical relationship so that $c_{\mathrm{p}}$-based estimates vary between $0.89 \pm 0.84$ 

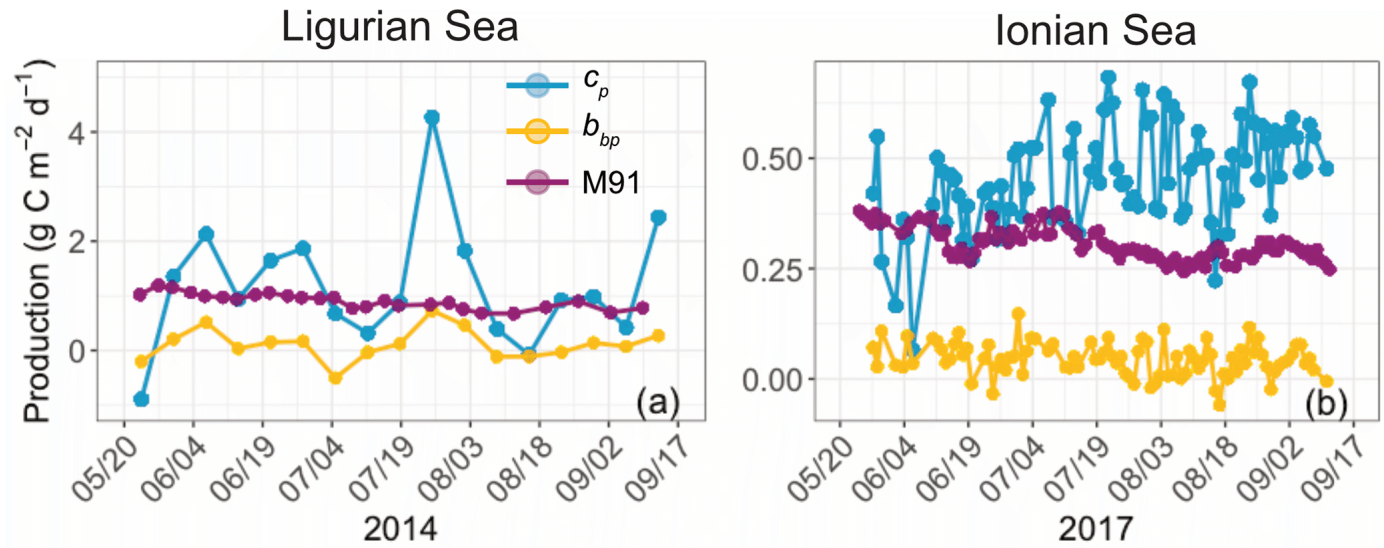

Figure 6. Comparison of the biological production integrated within the euphotic layer, derived from the diel cycle of $c_{\mathrm{p}}$ (blue) or $b_{\mathrm{bp}}$ (yellow) or computed using the bio-optical primary production model of Morel (1991) (M91; purple) for the Ligurian Sea (a) and the Ionian Sea (b). Please note that the date format in this figure is month/day.

Table 4. Estimates of primary and community production (in units of $\mathrm{gC} \mathrm{m}^{-2} \mathrm{~d}^{-1}$ ) from the literature in areas of the Mediterranean Sea comparable, when possible, to the considered study regions.

\begin{tabular}{|c|c|c|c|c|c|}
\hline \multicolumn{6}{|l|}{ Primary production } \\
\hline Method & Reference & Area & Period & Layer & Estimate \\
\hline \multirow{6}{*}{$\begin{array}{l}\text { Ocean color-coupled } \\
\text { bio-optical model }\end{array}$} & Morel and André (1991) & Western basin & 1981 & $0-Z_{\mathrm{eu}}$ & 0.26 \\
\hline & Antoine et al. (1995) & Whole basin & 1979-1981 & $0-1.5 Z_{\mathrm{eu}}$ & 0.34 \\
\hline & Bosc et al. (2004) & Western basin & $1998-2001$ & $0-1.5 Z_{\mathrm{eu}}$ & 0.45 \\
\hline & - & Eastern basin & - & - & 0.33 \\
\hline & Uitz et al. (2012) & Bloom region & May-Aug 1998-2007 & $0-1.5 Z_{\mathrm{eu}}$ & $0.26-0.82$ \\
\hline & - & No-bloom region & - & - & $0.22-0.69$ \\
\hline \multirow[t]{3}{*}{ Biogeochemical model } & Lacroix and Nival (1998) & Ligurian Sea & & $0-200 \mathrm{~m}$ & 0.13 \\
\hline & Allen et al. (2002) & Ligurian Sea & & $0-Z_{\mathrm{eu}}$ & 0.33 \\
\hline & - & Ionian Sea & & - & 0.14 \\
\hline \multirow{4}{*}{$\begin{array}{l}\text { In situ }{ }^{14} \mathrm{C} \\
\text { measurements }\end{array}$} & Minas (1970) & Northwestern basin & $1961-1965$ & Surface & 0.21 \\
\hline & $\begin{array}{l}\text { Magazzu and Decembrini } \\
\text { (1995) }\end{array}$ & Ionian Sea & 1983-1992 & $0-Z_{\mathrm{eu}}$ & 0.22 \\
\hline & Turley et al. (2000) & Ligurian Sea & Oct 1997, Apr-May 1998 & $0-Z_{\mathrm{eu}}$ & 0.5 \\
\hline & Marañón et al. (2021) & Ionian Sea & May 2017 & $0-200 \mathrm{~m}$ & 0.19 \\
\hline \multicolumn{6}{|c|}{ Gross community production } \\
\hline Method & Reference & Area & Period & Layer & Estimate \\
\hline $\begin{array}{l}c_{\mathrm{p}} \text { diel-cycle-based } \\
\text { method }\end{array}$ & Barnes and Antoine (2014) & Ligurian Sea & May-Aug 2006-2011 & $0-Z_{\mathrm{eu}}$ & $0.8-1.5$ \\
\hline
\end{tabular}


Table 5. Comparison of the mean rates $\pm \mathrm{SD}\left(\mathrm{gC} \mathrm{m}^{-2} \mathrm{~d}^{-1}\right)$ of the community production integrated within the euphotic layer, derived from the application of the bio-optical diel-cycle-based method to the $c_{\mathrm{p}}$ measurements, using different bio-optical relationships from the literature for converting the $c_{\mathrm{p}}$ values into POC biomass.

\begin{tabular}{lrc}
\hline Reference & Ligurian Sea & Ionian Sea \\
\hline Marra et al. (1995) & $0.89 \pm 0.84$ & $0.35 \pm 0.09$ \\
Claustre et al. (1999) & $1.22 \pm 1.16$ & $0.48 \pm 0.12$ \\
Oubelkheir et al. (2005) & $1.18 \pm 1.13$ & $0.46 \pm 0.11$ \\
Behrenfeld and Boss (2006) & $1.43 \pm 1.35$ & $0.56 \pm 0.14$ \\
Gardner et al. (2006) & $0.93 \pm 0.88$ & $0.36 \pm 0.09$ \\
Stramski et al. (2008) & $1.62 \pm 1.54$ & $0.63 \pm 0.16$ \\
Loisel et al. (2011) & $0.98 \pm 0.92$ & $0.38 \pm 0.10$ \\
Cetinić et al. (2012) & $0.96 \pm 0.91$ & $0.37 \pm 0.09$ \\
\hline
\end{tabular}

and $1.62 \pm 1.54 \mathrm{gC} \mathrm{m}^{-2} \mathrm{~d}^{-1}$ in the Ligurian Sea and between $0.35 \pm 0.09$ and $0.63 \pm 0.16 \mathrm{gC} \mathrm{m}^{-2} \mathrm{~d}^{-1}$ in the Ionian Sea. The minimal and maximal values are obtained with the biooptical relationships from Marra et al. (1995) and Stramski et al. (2008), respectively (Table 5). Compared to the reference value obtained using the Oubelkheir et al. (2005) relationship, the $c_{\mathrm{p}}$-based estimates are $25 \%$ lower and $37 \%$ higher using the relationships of Marra et al. (1995) and Stramski et al. (2008), respectively. We also note that using the Mediterranean relationship of Loisel et al. (2011), instead of that of Oubelkheir et al. (2005), would reduce the $c_{\mathrm{p}}$-based estimates by $17 \%$ in both study regions (Table 5). That said, although the absolute magnitudes vary depending upon proxy choice, the differences observed between locations is robust.

The use of the single relationship established from Mediterranean waters (Oubelkheir et al., 2005) appears to be a reasonable choice for the study region. Yet, if more relevant bio-optical proxy relationships are available, such as one that accounts for spatial and seasonal variations, as well as even being applicable to different layers of the water column, these would certainly reduce the uncertainty in the rate estimation. Although this is beyond the scope of the present study, we recognize that such investigations should be conducted in the future in order to refine optics-based biomass (POC) and community production estimates.

\subsection{Regional and vertical variability of production}

The temporal evolution of the $c_{\mathrm{p}}$-derived POC biomass integrated within the three distinct layers of the water column is presented for the two study regions in Fig. 7. The integrated POC concentration values follow similar temporal trends as reported for $c_{\mathrm{p}}$ (Figs. 3-4). In the Ligurian Sea, the euphotic-layer-integrated $\mathrm{POC}$ varies between 1.5 and $6.0 \mathrm{gC} \mathrm{m}^{-2}$ (mean of $3.7 \pm 1.1 \mathrm{gC} \mathrm{m}^{-2}$; Fig. 7a and Table 6). There was a decrease from late May to mid-July (6.0 to $\left.1.5 \mathrm{gC} \mathrm{m}^{-2}\right)$ followed by a moderate peak $\left(3.9 \mathrm{gC} \mathrm{m}^{-2}\right)$ between mid-July and mid-August (as bounded by the dashed lines in Fig. 5). The $c_{\mathrm{p}}$-based community production did exhibit large variability over the time period (Fig. $7 \mathrm{~b}$ and Table 6), but interestingly, the moderate POC peak observed in the core of the oligotrophic season (between mid-July and mid-August) is associated with the maximum production rate of the time series $\left(4.3 \mathrm{gC} \mathrm{m}^{-2} \mathrm{~d}^{-1}\right)$.

In the Ionian Sea, the POC biomass integrated within the euphotic zone is much lower than in the Ligurian Sea and remains more stable over the time period $\left(1.9 \pm 0.24 \mathrm{gC} \mathrm{m}^{-2}\right.$; Fig. 7c and Table 6). As with POC, the community production is much lower in the Ionian Sea than in the Ligurian Sea but still exhibits substantial variability with values ranging within $0.06-0.68 \mathrm{gC} \mathrm{m}^{-2} \mathrm{~d}^{-1}$ (Fig. 7d). These results are consistent with multiple studies reporting a large difference in the trophic status and productivity of the Ligurian and Ionian seas, on seasonal and annual timescales (D'Ortenzio and Ribera d'Alcala, 2009; Siokou-Frangou et al., 2010; Lavigne et al., 2013; Mayot et al., 2016). Our results confirm this difference yet on a monthly timescale during the oligotrophic summer period.

The gross community production estimates integrated over different layers of the water column reveal distinct patterns. In the Ligurian Sea, both the euphotic and SCM layers show large production rates $\left(0.96 \pm 1.3 \mathrm{gC} \mathrm{m}^{-2} \mathrm{~d}^{-1}\right)$, with production in the SCM layer frequently equaling or overtaking the production in the euphotic layer (Fig. 7b). This is particularly striking in late July, when the production peak is actually associated with a large enhancement of the production in the SCM layer $\left(4.9 \mathrm{gC} \mathrm{m}^{-2} \mathrm{~d}^{-1}\right)$. In contrast, the surface layer shows reduced production rates $\left(0.29 \pm 0.33 \mathrm{gC} \mathrm{m}^{-2} \mathrm{~d}^{-1}\right)$, a pattern also observed in the Ionian Sea $\left(0.11 \pm 0.04 \mathrm{gC} \mathrm{m}^{-2} \mathrm{~d}^{-1}\right)$. In the Ionian Sea, the production is maximal in the euphotic zone and very variable and occasionally larger in the SCM layer $\left(0.14 \pm 0.39 \mathrm{gC} \mathrm{m}^{-2} \mathrm{~d}^{-1}\right.$; Fig. $\left.7 \mathrm{~d}\right)$. The bio-optical dielcycle-based method produces several occurrences of negative values in the SCM layer, indicating that the 1D assumption is occasionally not satisfied in the lower part of the euphotic layer. This could arise when physical processes that transport particles are larger than local growth and loss of POC.

Our results support the hypothesis raised in previous studies (e.g., Mignot et al., 2014; Barbieux et al., 2019) that, in the Ligurian temperate-like system, the SCM, which is in fact a SBM, may be highly productive. Conversely, in the Ionian region, which shows similarities with subtropical stratified oligotrophic systems, the SCM primarily reflects photoacclimation and is less productive. Beyond these mean regional trends, both SCM systems exhibit some temporal variability in production, a somewhat unexpected pattern at the core of the presumably stable oligotrophic season. 
Table 6. Mean values \pm SD of the stock of particulate organic carbon (POC) and rate of gross community production (GCP) derived from the diel cycle of $c_{\mathrm{p}}$ in the two considered regions. The values are integrated within the surface, subsurface maximum (SCM) and euphotic layers.

\begin{tabular}{lrrr|rrr}
\hline & \multicolumn{3}{c}{ Ligurian Sea } & \multicolumn{3}{c}{ Ionian Sea } \\
\cline { 2 - 7 } Variable & Euphotic & Surface & SCM & Euphotic & Surface & SCM \\
\hline POC $\left(\mathrm{gC} \mathrm{m}^{-2}\right)$ & $3.67 \pm 1.11$ & $0.36 \pm 0.17$ & $3.86 \pm 1.20$ & $1.88 \pm 0.24$ & $0.34 \pm 0.14$ & $0.93 \pm 0.31$ \\
GCP $\left(\mathrm{gC} \mathrm{m}^{-2} \mathrm{~d}^{-1}\right)$ & $1.18 \pm 1.13$ & $0.29 \pm 0.33$ & $0.96 \pm 1.28$ & $0.46 \pm 0.11$ & $0.11 \pm 0.04$ & $0.14 \pm 0.39$ \\
\hline
\end{tabular}
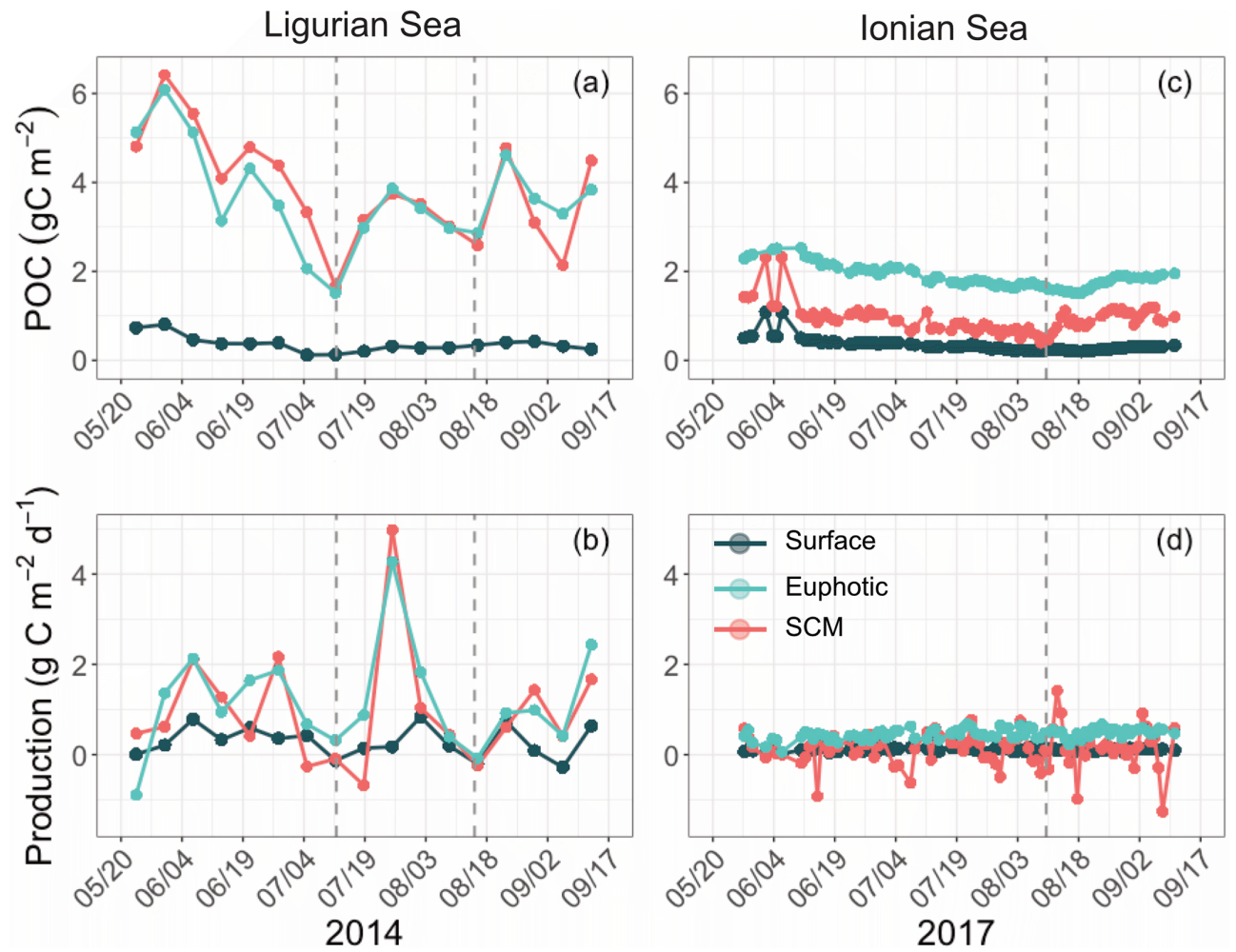

Figure 7. Temporal evolution of the POC and community production derived from the diel cycle of $c_{\mathrm{p}}$ in the Ligurian Sea (a, b) and the Ionian Sea (c, d) and integrated in three different layers of the water column: surface (dark green), euphotic (light blue) and SCM (red) layers. The dotted lines indicate the dates when $c_{\mathrm{p}}$ in the SCM layer reaches a minimum. Please note that the date format in this figure is month/day.

\subsection{Production in the SCM layer in relation to the biotic and abiotic context}

Here we investigate the temporal variability in the SCM layer production and attempt to interpret the observed patterns in the context of biological and abiotic conditions.

\subsubsection{Phytoplankton and particulate assemblage}

The pigment data collected during the BOUSSOLE and PEACETIME cruises concomitantly with the deployments of the fLig and fIon floats, respectively, are used as proxies for phytoplankton community structure (Fig. 8). In the Ligurian Sea, nanophytoplankton (mainly prymnesiophytes) appear to be dominant contributors to the phytoplankton as- semblage both in the surface layer ( $48 \pm 8 \%$; Fig. 8 b) and SCM layer $(54 \pm 10 \%)$. Picophytoplankton (prokaryotes and small chlorophytes) and microphytoplankton (diatoms and dinoflagellates) are present in moderate proportions, with $30 \pm 11 \%$ and $22 \pm 5 \%$ in the upper layer and $19 \pm 7 \%$ and $27 \pm 9 \%$ in the SCM layer, respectively (Fig. 8a and c). No marked shift in the community composition is observed during the time series, although an occasional increase in the contribution of microphytoplankton is observed in the SCM layer, with no clear temporal trend (Fig. 8a and Appendix B). In the Ionian Sea, the surface layer displays large contribution of nanophytoplankton ( $56 \pm 2 \%$; Fig. $8 \mathrm{e}$ ) and, to a lesser extent, picophytoplankton (29 $\pm 3 \%$; Fig. 8d). However, the SCM level is characterized by an enhanced contribution of microphytoplankton (diatoms) to the algal as- 
semblage ( $49 \pm 5 \%$; Fig. $8 \mathrm{f}$ ), as discussed in Marañón et al. (2021). The Ionian PEACETIME data were limited to the period from 25 to 28 May 2017, and thus it was not possible to determine whether the composition of phytoplankton communities evolved with time. Although not characterized by the prokaryotic populations (Synechococcus and Prochlorococcus) that typically prevail in stratified oligotrophic environments, our observations are consistent with previous studies reporting enhanced contributions of nanophytoplankton (e.g., Gitelson et al., 1996; Vidussi et al., 2001) and the occurrence of diatoms at depth (Siokou-Frangou et al., 2010; Crombet et al., 2011; Marañón et al., 2021) in the Mediterranean Sea.

Bio-optical properties and their ratios provide an indication about variations in the constituents (algal or nonalgal) and the size of the particulate pool, the composition of the phytoplankton assemblage, and the physiological status of phytoplankton cells (e.g., Geider, 1987; Ulloa et al., 1994; Stramski et al., 2004; Loisel et al., 2007). Here we consider the bio-optical ratios $b_{\mathrm{bp}} / c_{\mathrm{p}}, c_{\mathrm{p}} / \mathrm{Chl}$ and $b_{\mathrm{bp}} / \mathrm{Chl}$ in the SCM layer (Fig. 9). The $b_{\mathrm{bp}} / c_{\mathrm{p}}$ ratio, while at slightly different wavelengths (700 and $660 \mathrm{~nm}$, respectively), is at absorption minima, and thus this ratio is comparable to the backscattering ratio $b_{\mathrm{bp}} / b_{\mathrm{p}}$. The $b_{\mathrm{bp}} / b_{\mathrm{p}}$ ratio is a demonstrated proxy for determining the relative constituent composition (Twardowski et al., 2001), with phytoplankton exhibiting lower ratios than nonalgal particles (approximately $0.5 \%$ and $1 \%$, respectively; Boss et al., 2004; Whitmire et al., 2007; Westberry et al., 2010). The $b_{\mathrm{bp}} / \mathrm{Chl}$ and $c_{\mathrm{p}} / \mathrm{Chl}$ ratios are both proxies for the $\mathrm{POC} / \mathrm{Chl}$ ratio (e.g., Claustre et al., 1999; Oubelkheir et al., 2005; Behrenfeld et al., 2015; Álvarez et al., 2016) and thus an indicator of the contribution of phytoplankton to the whole organic carbon pool. The variations are also interpreted as changes in the composition of phytoplankton communities (e.g., Sathyendranath et al., 2009) and their acclimation to the light-nutrient regime (e.g., Geider et al., 1987; Loisel and Morel, 1998; Geider et al., 1997; Cloern, 1999) if one assumes that nonalgal particles are negligible (e.g., as indicated by the backscattering ratio) or not varying in concentration. The differences between the $b_{\mathrm{bp}} / \mathrm{Chl}$ and $c_{\mathrm{p}} / \mathrm{Chl}$ ratios lie in the fact that they are sensitive to different particle size ranges (Roesler and Boss, 2008), and, thus, when they are not correlated, one can qualitatively discern differing dynamics across the phytoplankton size spectrum.

The $b_{\mathrm{bp}} / c_{\mathrm{p}}$ ratio is very different between the Ligurian and Ionian seas, with significantly lower values in the Ligurian Sea $(0.0068 \pm 0.0009$ and $0.0095 \pm 0.0009$; Fig. 9). These ratios indicate that, in the general sense, the Ligurian Sea SCM is more phytoplankton dominated than the Ionian Sea $\mathrm{SCM}$, which tends towards nonalgal particles. In the Ligurian Sea, the $b_{\mathrm{bp}} / c_{\mathrm{p}}$ ratio remains $<0.0087$ and reaches a minimum of 0.0055 over the period coinciding with the production event from mid-July to mid-August (Fig. 9a), consistent with phytoplankton dominance. In contrast, in the Ionian Sea
$\mathrm{SCM}$, the $b_{\mathrm{bp}} / c_{\mathrm{p}}$ ratio increases from 0.0085 in late May, peaking at nearly 0.012 in early August and then decreasing back to 0.0085 in September (Fig. 9b). The tendency towards a ratio of 0.01 (or $1 \%$ ) in the core of the oligotrophic season evidences the increased proportion of nonalgal particles to the bulk pool as previously observed in oligotrophic environments (Yentsch and Phinney, 1989; Stramski et al., 2004; Loisel et al., 2007).

The ratios of $c_{\mathrm{p}}$ and $b_{\mathrm{bp}}$ to $\mathrm{Chl}$ exhibit not only different temporal patterns between the Ligurian and Ionian Sea SCMs but also different relative values. The $c_{\mathrm{p}} / \mathrm{Chl}$ ratio in the Ligurian Sea SCM is higher than that of the Ionian Sea, ranging from 0.18 to $0.45 \mathrm{~m}^{2} \mathrm{mg} \mathrm{Chl}^{-1}$ (mean value of $0.29 \pm 0.06 \mathrm{~m}^{2} \mathrm{mg} \mathrm{Chl}^{-1}$ ), compared to 0.15 to $0.26 \mathrm{~m}^{2} \mathrm{mg} \mathrm{Chl}^{-1}$ (mean value of $0.20 \pm 0.03 \mathrm{~m}^{2} \mathrm{mg} \mathrm{Chl}^{-1}$ ), respectively. These results are consistent with the study of Loisel and Morel (1998), reporting low values ranging within $0.1-0.2 \mathrm{~m}^{2} \mathrm{mg} \mathrm{Chl}^{-1}$ at the deep chlorophyll maximum level of oligotrophic sites. In contrast, although the $b_{\mathrm{bp}} / \mathrm{Chl}$ ratio in the Ligurian Sea SCM ranges from 0.0011 to $0.0023 \mathrm{~m}^{2} \mathrm{mg} \mathrm{Chl}^{-1}$ and in the Ionian Sea from 0.0015 to $0.0021 \mathrm{~m}^{2} \mathrm{mg} \mathrm{Chl}^{-1}$, they have essentially identical mean values over the time series $(0.0017 \pm 0.0006$ and $0.0017 \pm 0.0001$, respectively). With the $b_{\mathrm{bp}} / \mathrm{Chl}$ ratio being more sensitive to small-sized particles than the $c_{\mathrm{p}} / \mathrm{Chl}$ ratio, these results suggest that, in the SCM layer, the POC in the small size fractions of the Ligurian and Ionian seas is more similar than that in the large size fractions.

Temporally, the Ligurian Sea SCM exhibits significantly more temporal variations in both ratios compared to the Ionian Sea SCM, and the temporal variations are highly correlated. Both the $c_{\mathrm{p}} / \mathrm{Chl}$ and $b_{\mathrm{bp}} / \mathrm{Chl}$ ratios in the Ligurian Sea SCM exhibit a peak at the start of the time series in late May that decreases to mid-July, followed by a second peak during the period coinciding with the production episode from mid-July to mid-August and then a third increase until the end of the time series (Fig. 9b-c). In contrast, both ratios in the Ionian Sea SCM exhibit significantly reduced temporal variability (Fig. 9e-f), with a weak increase observed starting in early August.

Despite differing temporal variability, the $b_{\mathrm{bp}} / \mathrm{Chl}$ ratio in both seas remains moderate to low $\left(<0.0025 \mathrm{~m}^{2} \mathrm{mg} \mathrm{Chl}^{-1}\right.$; Fig. 9c and f), consistent with global SCM values (Barbieux et al., 2018). The enhanced $b_{\mathrm{bp}} / \mathrm{Chl}$ values observed in the Ligurian Sea SCM in early May, late July and late August suggest an increased contribution of small (picoand nano-sized) phytoplankton (Cetinić et al., 2012, 2015). Yet, the BOUSSOLE pigment data do not reveal pronounced changes in the phytoplankton assemblage. Low-light conditions typically prevailing in the SCM layer are usually associated with low values of the $c_{\mathrm{p}} / \mathrm{Chl}$ and $b_{\mathrm{bp}} / \mathrm{Chl}$ ratios (e.g., Loisel and Morel, 1998; Behrenfeld and Boss, 2003; Westberry et al., 2008; Barbieux et al., 2019). These low values may reflect photoacclimation, by which phytoplankton organisms increase their intracellular $\mathrm{Chl}$, and/or an in- 

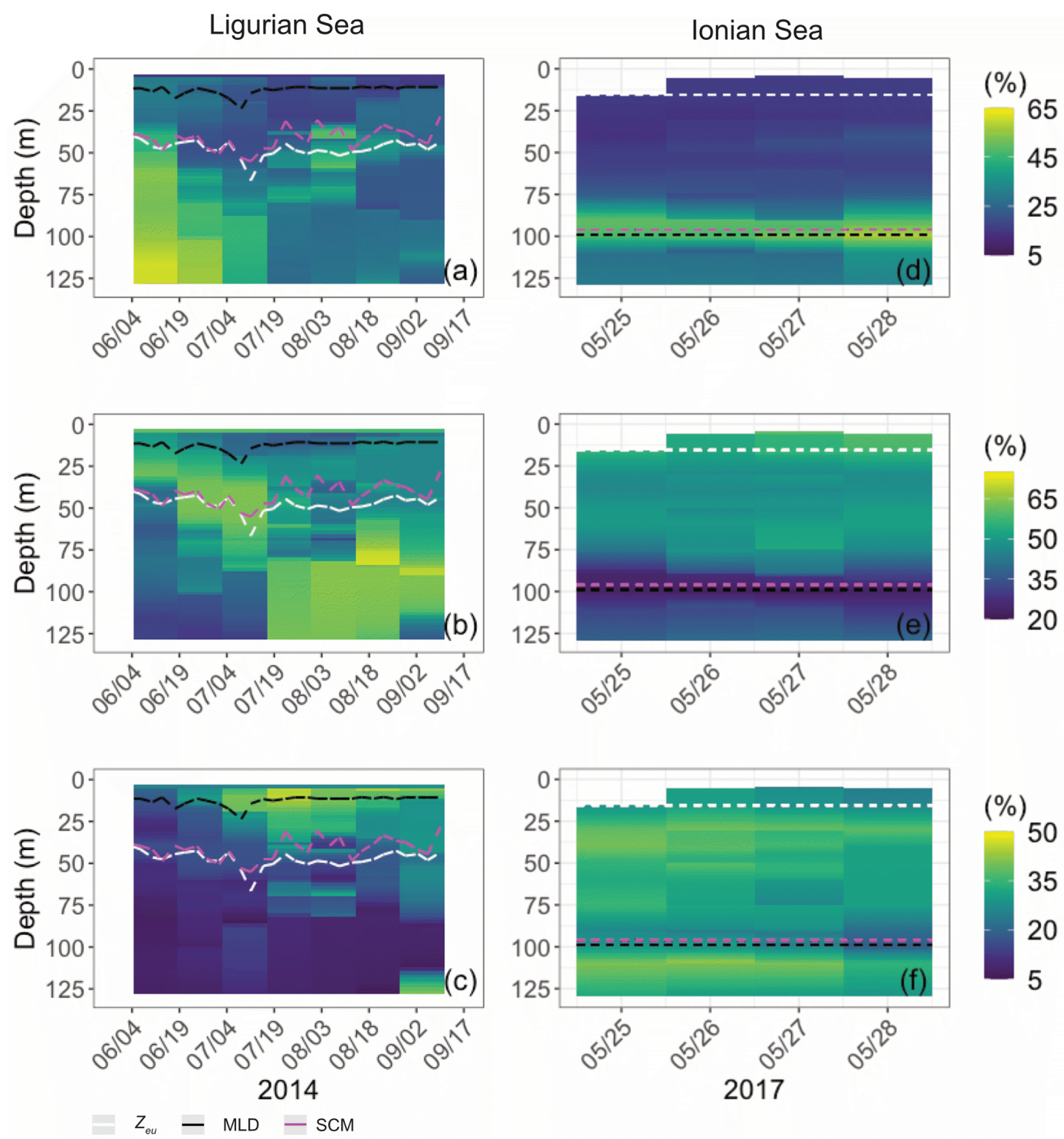

Figure 8. Depth-interpolated time series of the relative contributions (\%) to the chlorophyll $a$ concentration of the micro- (a, d), nano$(\mathbf{b}, \mathbf{e})$ and picophytoplankton $(\mathbf{c}, \mathbf{h})$ derived from HPLC pigment determinations in the Ligurian Sea (BOUSSOLE site; a-c) and Ionian Sea (PEACETIME cruise; d-f). The pigment data were collected at the BOUSSOLE site in the same region and at the same time period as the fLig float deployment (see text Sect. 2.1). The fIon float was deployed concurrently to sampling for HPLC pigments at the PEACETIME ION station. Pigment data collected at ION over $4 \mathrm{~d}$ prior to float deployment are shown. As an indication, the euphotic depth $\left(Z_{\text {eu }}\right.$; white dashed line), the mixed-layer depth (MLD; black dashed line) and the depth of the SCM (magenta dashed line) derived from the BGC-Argo float measurements, as in Fig. 3, are overlaid onto the pigment data. Please note that the date format in this figure is month/day.

crease in the fluorescence-to-Chl ratio in relation to limited or null non-photochemical chlorophyll fluorescence quenching. Nevertheless, the temporal variability in the $c_{\mathrm{p}} / \mathrm{Chl}$ and $b_{\mathrm{bp}} / \mathrm{Chl}$ values may be resulting from fluctuations in the light conditions at the SCM in the Ligurian Sea. In the Ionian Sea, the invariant low $c_{\mathrm{p}} / \mathrm{Chl}$ and $b_{\mathrm{bp}} / \mathrm{Chl}$ values are consistent with both the photoacclimation of phytoplankton to low-light conditions and a diatom-dominated phytoplankton assemblage (Cetinić et al., 2015; Barbieux et al., 2018). The relatively stable ratios observed in this region suggest a relative steadiness in the composition of the phytoplankton assemblage over the considered period.

\subsubsection{Relation to abiotic conditions}

The Ligurian Sea exhibits enhanced community production during the period from mid-July to mid-August 2014, which is associated with a comparatively moderate increase in the biomass indicators (Figs. 3-4) and $c_{\mathrm{p}}$-derived POC (Fig. 7a). During this time period, the depth of the SCM shoals by 

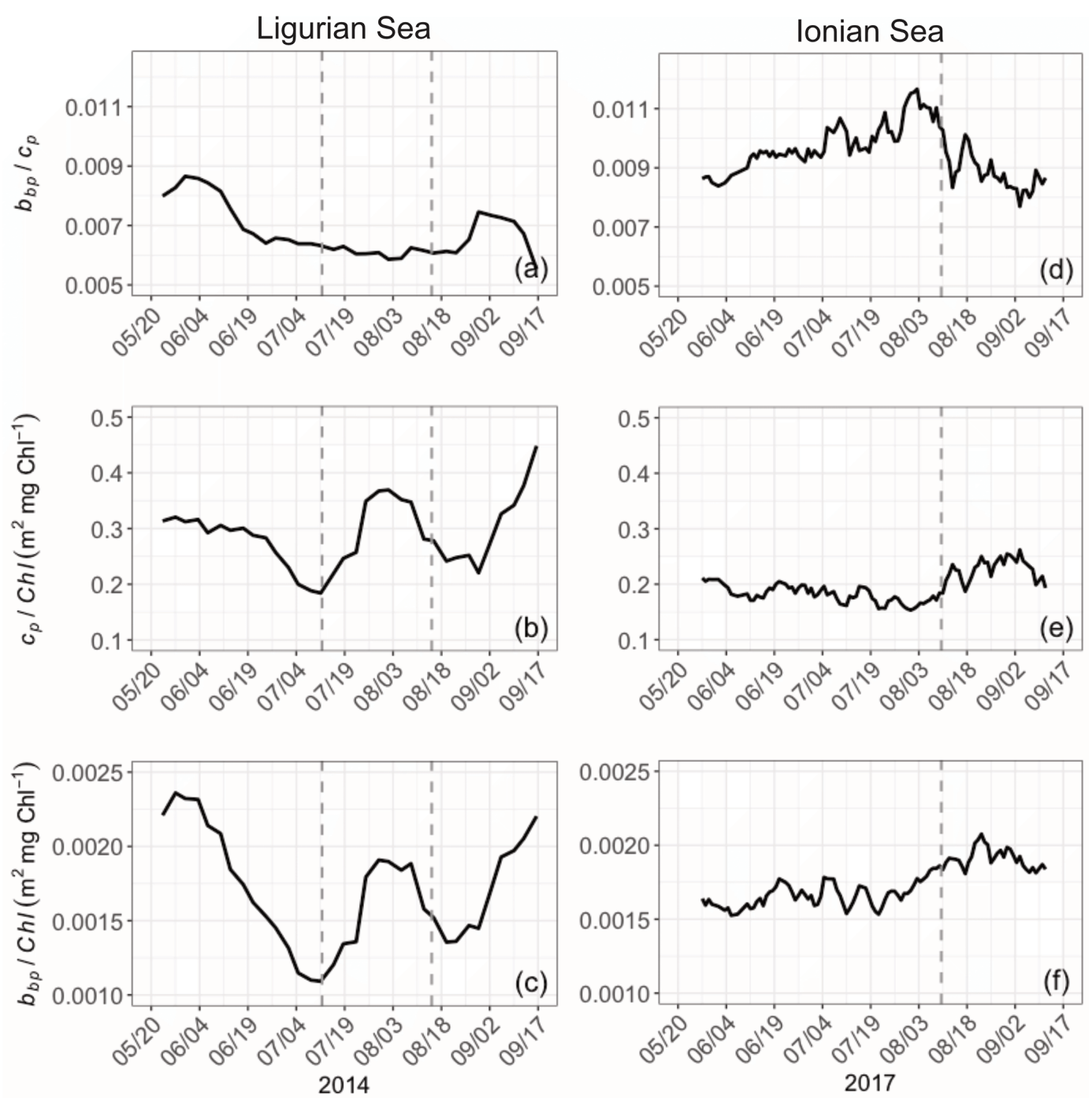

Figure 9. Temporal evolution of the bio-optical ratios of $b_{\mathrm{bp}} / c_{\mathrm{p}}(\mathbf{a}), c_{\mathrm{p}} / \mathrm{Chl}(\mathbf{b})$ and $b_{\mathrm{bp}} / \mathrm{Chl}(\mathbf{c})$ in the SCM layer for the Ligurian Sea (a-c) and the Ionian Sea (d-f). The dotted lines indicate the dates when the values of $c_{\mathrm{p}}$ in the SCM layer reach a minimum. Please note that the date format in this figure is month/day.

$25 \mathrm{~m}$. This change occurs concurrently with a slight shoaling of the density isopycnals (Fig. 3a-c) and a doubling (from 0.5 to 1 mol quanta $\mathrm{m}^{-2} \mathrm{~d}^{-1}$ ) in the daily PAR within the SCM layer (Fig. 10a). Therefore, we suggest that the observed production episode may result from physical forcing that induces an upwelling of the water mass, thereby resulting in an alleviation of the light-nutrient limitation and an adequate balance between light and nutrient availability in the SCM layer. This SCM production episode is associated with a moderate phytoplankton biomass $\left(0.8 \mathrm{Chl} \mathrm{mg} \mathrm{m}^{-3}\right)$, dominated by a nanoplankton community. It coincides with an increase in the $c_{\mathrm{p}} / \mathrm{Chl}$ and $b_{\mathrm{bp}} / \mathrm{Chl}$ ratios, which we attribute to a boost in the carbon-to-Chl ratio resulting from production in enhanced light conditions. Because it appears to result from changes in light conditions, we may attribute this production event to photosynthetic (not community) growth.
In the Ionian Sea, the depth of the SCM follows the depth of the isopycnal 28.85 during the period from late to May to mid-August 2017 (Fig. 3d-f). In mid-August, the SCM reaches its deepest point $(\sim 125 \mathrm{~m})$, concurrent with deepening isopycnals; decreased PAR levels within the SCM layer (Fig. 10b); and minimum values of Chl, $c_{\mathrm{p}}$ and $b_{\mathrm{bp}}$. Afterwards, the SCM depth decouples from the position of the isopycnals (Fig. 3d-f); the SCM becomes shallower; and the mean daily PAR in the SCM layer increases. Nevertheless, the observed temporal fluctuations in the abiotic forcing and biological indicators do not seem to relate to any clear change in the community production (Fig. $7 \mathrm{~d}-\mathrm{f}$ ). This suggests that physics-induced changes in the position of the SCM are not sufficient to alleviate the light and/or nutrient limitation occurring at this time in the study location (Guieu et al., 2020a). Considering the large contribution of diatoms at the SCM, 
one may conclude that the low, yet non-negligible, production levels estimated in the SCM layer are supported by diatoms. This result supports previous findings that indicate, contrary to the classic view of diatoms thriving essentially in dynamic eutrophic conditions, these organisms have the ability to maintain in stratified oligotrophic environments, including in deep layers under low-light-nutrient conditions (Kemp and Villareal, 2013; Kemp and Villareal, 2018). This was also highlighted by Marañón et al. (2021) based on observations in the Mediterranean Sea (PEACETIME cruise).

\subsection{Contribution of the SCM to the water column production}

In order to assess the relative contribution of the SCM layer to the production occurring in the whole water column, we compare the $c_{\mathrm{p}}$-based estimates integrated within the productive $\left(0-1.5 Z_{\mathrm{eu}}\right)$ and SCM layers. Our results suggest that, for these oligotrophic systems, the production integrated within the SCM layer represents a substantial fraction $\left(F_{\mathrm{SCM}}\right)$ of the gross community production integrated within the productive layer. This is particularly the case for the Ligurian Sea, where $F_{\mathrm{SCM}}$ reaches $\sim 42 \%$, and to a lesser extent for the Ionian Sea with $F_{\mathrm{SCM}} \sim 16 \%$.

Subtropical stratified oligotrophic gyres cover $45 \%$ of the global ocean (McClain et al., 2004). Assuming that the Ionian Sea is representative of such systems (e.g., Mignot et al., 2014; Barbieux et al., 2019) and extrapolating the estimated relative contribution of the SCM layer to the water column production in the Ionian $\left(F_{\mathrm{SCM}} \sim 16 \%\right)$, the SCM layer would contribute $\sim 7 \%$ of the community production of the water column on a global scale (i.e., $F_{\mathrm{SCM}}$ of $16 \%$ multiplied by a global spatial occurrence of $45 \%$ ). In addition, using a global BGC-Argo database, Cornec et al. (2021) estimated that SCMs in oligotrophic subtropical gyres behave as an SBM $8 \%-42 \%$ of the year, depending on the season. Thus, assuming the Ligurian SCM oligotrophic summer system as a reference for an SBM, the contribution of the SCM layer to the global water column production could seasonally reach $19 \%$ (i.e., $F_{\mathrm{SCM}}$ of $42 \%$ multiplied by a global spatial occurrence of $45 \%$ ).

We recognize that these estimates are very crude and need to be refined and confirmed in future studies. Yet they suggest that the contribution of the SCM layer to the water column production may be significant globally, although commonly ignored. Our observations are consistent with previous findings in the Mediterranean Sea (Crombet et al., 2011; Marañón et al., 2021) and in other regions of the global ocean (Kemp and Villareal, 2013; Mignot et al., 2014) and suggest that stratified oligotrophic systems should no longer be considered steady oceanic deserts and that their biogeochemical contribution should be accounted for and better quantified to improve global carbon budgets.

\section{Conclusions}

The present study represents a first attempt to apply the biooptical diel-cycle-based method (Siegel et al., 1989; Claustre et al., 2008) to the $c_{\mathrm{p}}$ and $b_{\mathrm{bp}}$ coefficients measured by two BGC-Argo profiling floats. It aims to quantify gross community production in different layers of the water column, the subsurface chlorophyll maximum (SCM) layer in particular, during the oligotrophic summer season in two distinct systems of the Mediterranean, i.e., the Ligurian Sea and the Ionian Sea.

From a methodological point of view, our results indicate that, compared to the $c_{\mathrm{p}}$ coefficient, the diel cycle of the $b_{\mathrm{bp}}$ coefficient is not an optimal proxy for the daily POC variations regardless of the water column layer and (Ligurian or Ionian) region under consideration. These results have major implications for use of the methodology with geostationary ocean color missions and standard BGC-Argo profiling floats that yield only the $b_{\mathrm{bp}}$ coefficient. The present results thus argue in favor of a frequent implementation onto BGC-Argo floats of transmissometers ( $c_{\mathrm{p}}$ sensors), which provide information on a suite of key biogeochemical variables (Claustre et al., 2020), from phytoplankton community composition (Rembauville et al., 2017) to particle flux export (Briggs et al., 2011; Estapa et al., 2013) and, as demonstrated here, biological production (White et al., 2017; Briggs et al., 2018).

Our $c_{\mathrm{p}}$-based gross community production rates compare consistently with previous estimates from a similar approach applied to oligotrophic waters (Claustre et al., 2008; Gernez et al., 2011; Barnes and Antoine, 2014). Nevertheless, these estimates on average decrease by $25 \%$ or increase by $37 \%$ depending on the used $c_{\mathrm{p}}$-to-POC relationship, which is not negligible and raises the question of the selection of an empirical bio-optical relationship for converting $c_{\mathrm{p}}$ into a POC equivalent. Hence, we recommend POC sampling simultaneously to BGC-Argo float deployment. This will help to better constrain bio-optical relationships and ultimately improve the reliability of the biomass and production estimates.

Our results indicate that both the Ligurian and Ionian seas may sustain relatively large levels of gross community production during the oligotrophic summer period, with a substantial contribution by the SCM layer, a feature characteristic of oligotrophic systems that is typically considered steady and non-productive. Our results also suggest that the contribution of the SCM layer varies broadly depending the considered system, whether seasonally (Ligurian Sea) or permanently (Ionian) oligotrophic. These results agree with previous BGC-Argo-based studies describing the occurrence and functioning of SCM systems in the global ocean (Mignot et al., 2014; Cornec et al., 2021) and Mediterranean Sea (Lavigne et al., 2015; Barbieux et al., 2019) and offer a first attempt to quantify biological production in such systems.

Our study emphasizes the promising potential of BGCArgo profiling floats for providing a non-intrusive, highfrequency assessment of POC production within the whole 

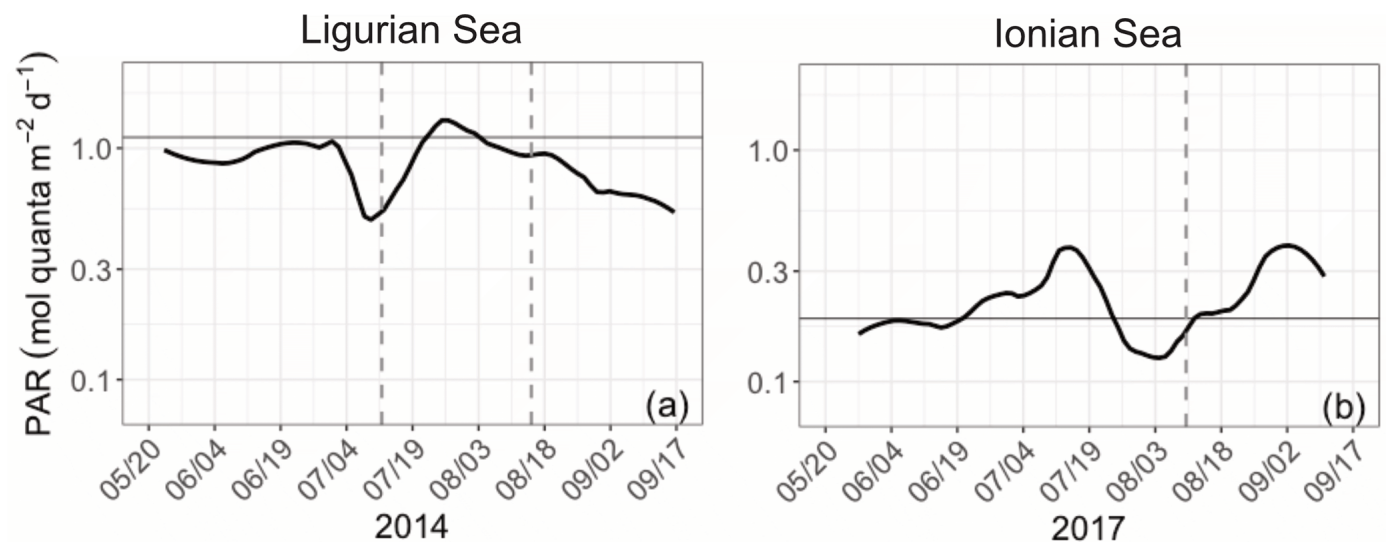

Figure 10. Time series of the daily integrated photosynthetically available radiation (PAR) at the SCM level in the Ligurian Sea (a) and the Ionian Sea (b). The horizontal grey line shows the median of each time series. The dotted lines indicate the dates at which the values of $c_{\mathrm{p}}$ in the SCM layer reach a minimum. Please note that the date format in this figure is month/day.

water column, which is critical in particular for applications to stratified oligotrophic environments with recurring or permanent SCMs. The present results, based on data from two Mediterranean environments, should be confirmed in the future through the deployment of "multi-profiling" BGC-Argo floats in the broad, remote subtropical gyres. In such systems, biological production is not constant but, instead, shows high temporal heterogeneity (Karl et al., 2003; Claustre et al., 2008) that may be missed by traditional sampling, leading to a potential underestimate of the biogeochemical impact of these systems in global carbon budgets. Implementing such a BGC-Argo-based approach to carbon flux quantification becomes even more important in the perspective of climate change, which is predicted to induce an expansion of stratified oligotrophic gyres and an oligotrophication of the oceans (Sarmiento et al., 2004) as already observed from satellite imagery (Polovina et al., 2008; Signorini et al., 2015). 


\section{Appendix A}

\section{Ligurian Sea}
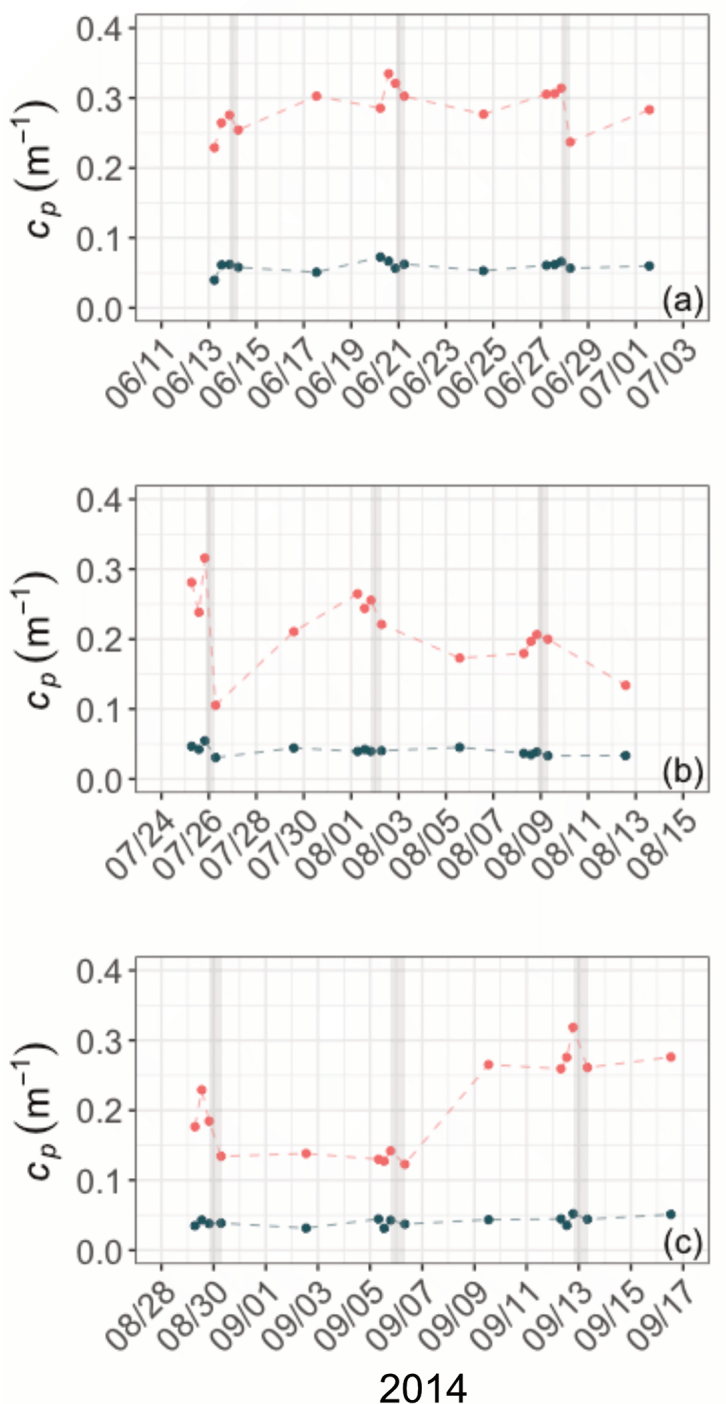

Ionian Sea
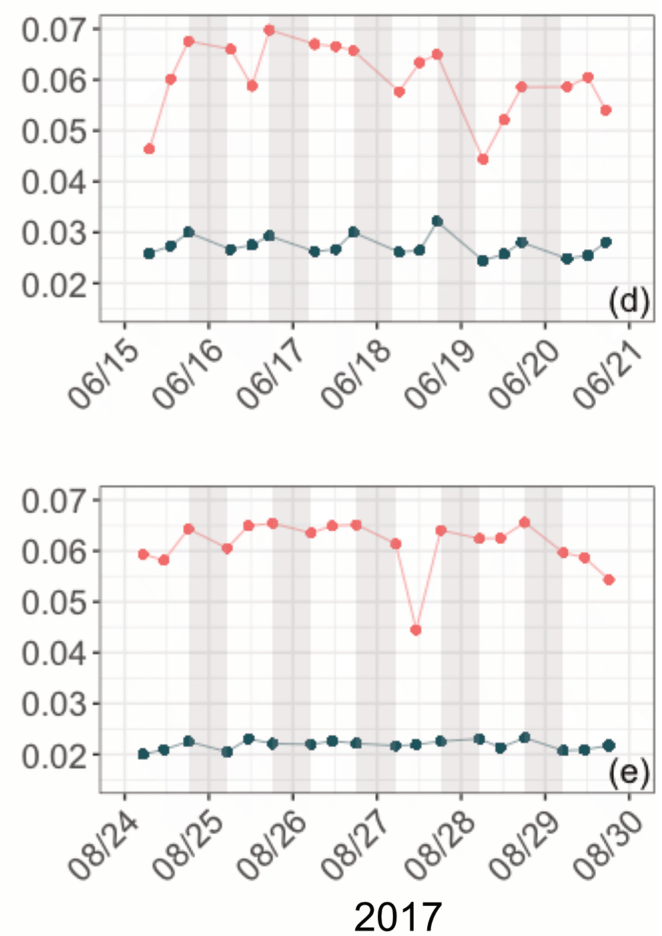

- Surface

- SCM

Figure A1. Example of time series of the $c_{\mathrm{p}}$ coefficient in the surface (red) and SCM (dark green) layers, chosen within the time periods indicated by the dashed lines in Figs. 3-4, from 24 May to 14 July 2014 (a), 14 July to 16 August 2014 (b) and 16 August to 13 September 2014 for the Ligurian Sea (a-c) and from 28 May to 11 August 2017 (d) and 11 August to 11 September 2017 (e) for the Ionian Sea (d-e). Please note that the date format in this figure is month/day. 
Ligurian Sea
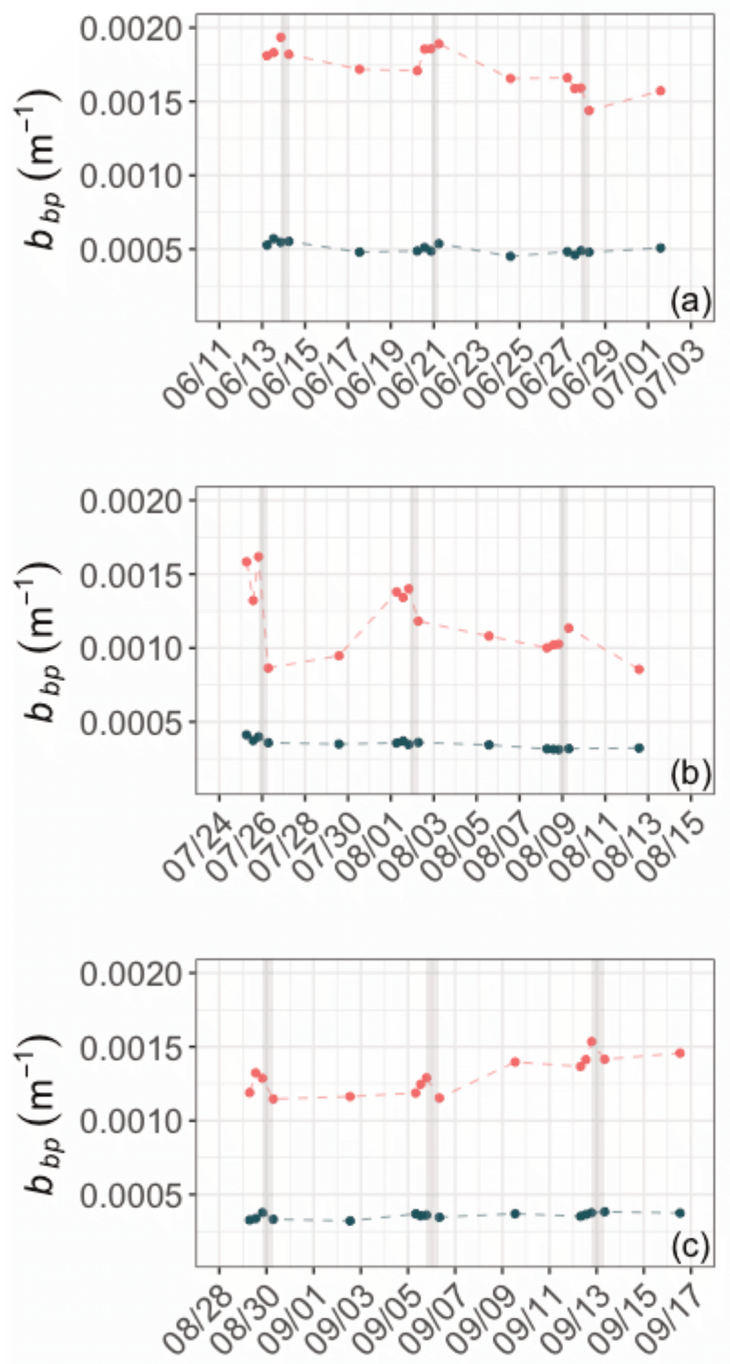

2014
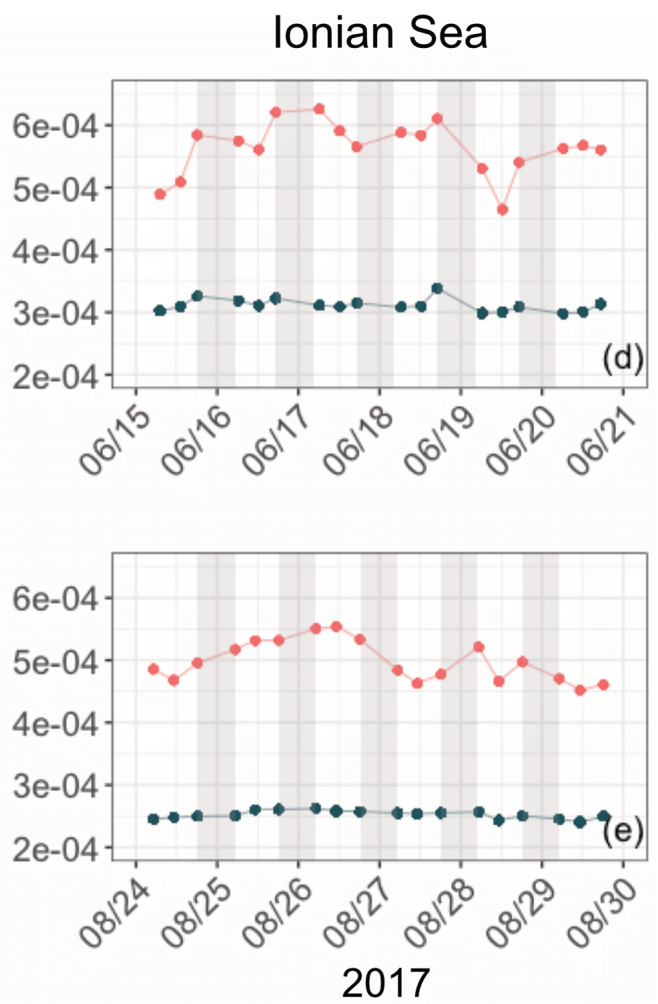

$\curvearrowright$ Surface SCM

Figure A2. Example of time series of the $b_{\mathrm{bp}}$ coefficient in the surface (red) and SCM (dark green) layers, chosen within the time periods indicated by the dashed lines in Figs. 3-4, from 24 May to 14 July 2014 (a), 14 July to 16 August 2014 (b) and 16 August to 13 September 2014 for the Ligurian Sea (a-c) and from 28 May to 11 August 2017 (d) and 11 August to 11 September 2017 (f) for the Ionian Sea (d-e). Please note that the date format in this figure is month/day. 


\section{Appendix B}

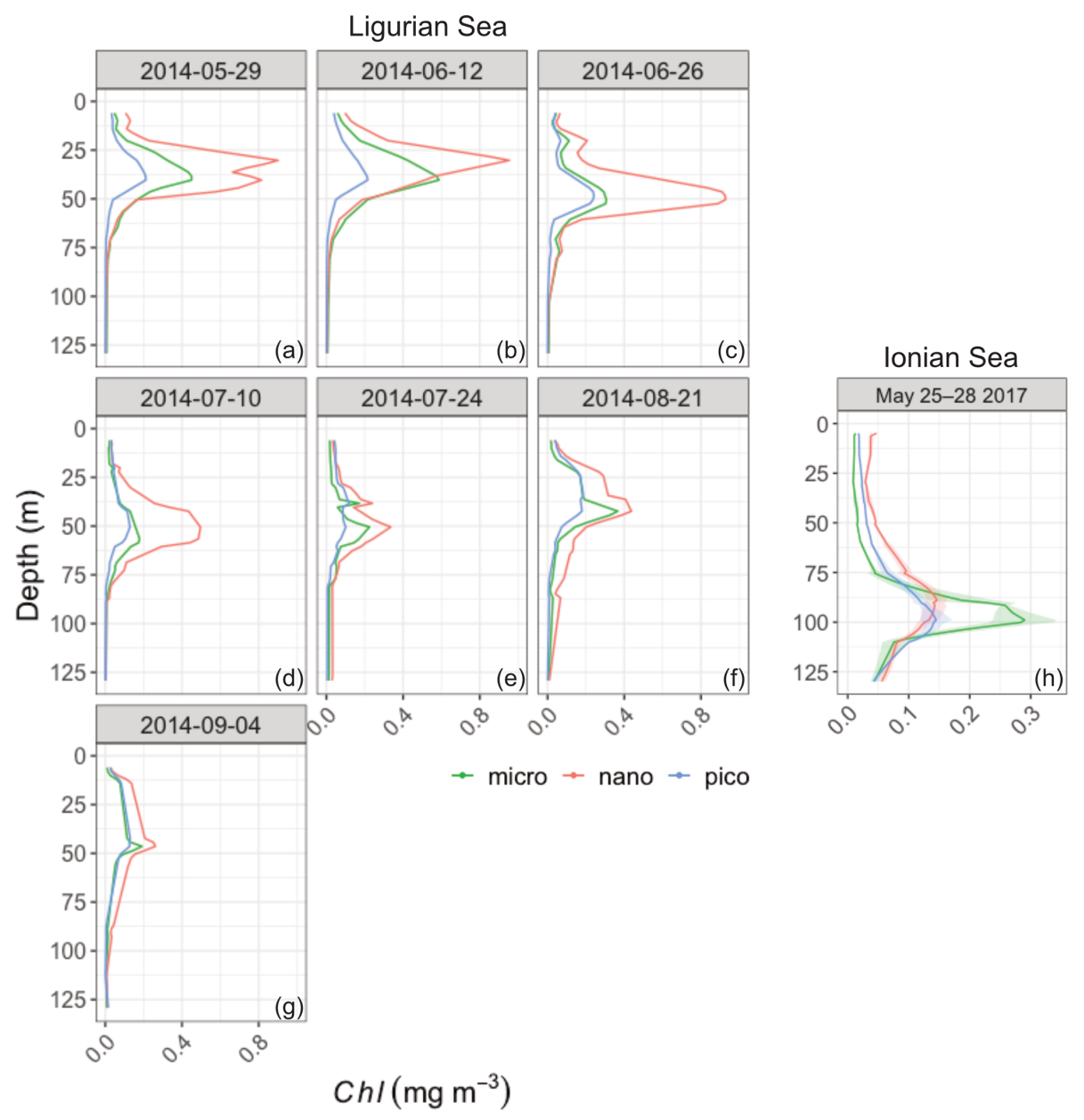

Figure B1. Vertical distribution of the chlorophyll $a$ concentration of the micro- (green), nano- (red) and picophytoplankton (blue) derived from HPLC pigment determinations in the Ligurian Sea (BOUSSOLE site; a-h) and the Ionian Sea (PEACETIME cruise; i). For the Ionian Sea the solid line shows the mean value, and the shaded area shows the standard deviation, calculated over a $4 \mathrm{~d}$ window (25-28 May 2017). Please note that the date formats in this figure are year-month-day and month day year.

Data availability. The BGC-Argo data and metadata were collected and made freely available by the international Argo program and the national programs that contribute to it (https://doi.org/10.17882/42182, Fumihiko et al., 2021). The Argo program is part of the Global Ocean Observing System. The PEACETIME project pigment data are available from the SEANOE archive (Guieu et al., 2020b). The BOUSSOLE program pigment data may be accessed upon request (http://www.obs-vlfr.fr/ Boussole/html/boussole_data/login_form.php, last access: 7 February 2022).
Author contributions. $\mathrm{MB}, \mathrm{JU}$ and $\mathrm{AB}$ designed the work and prepared the manuscript. $\mathrm{MB}$ processed the data and conducted the analyses. MB, JU and CR prepared the plots. AM and BG developed the biological-production model. AM helped with the implementation of the model and the interpretation of the output data. CR contributed to the analysis of the diel bio-optical variability, interpretation of bio-optical data and the organization of the manuscript. HC contributed to the interpretation of the BGC-Argo data and biological production. HL helped with the interpretation of the bio-optical data and the global extrapolation of the results. VT and FD'O contributed to the BGC-Argo float deployments and interpretation of the physical data. AP prepared and tested the BGC-Argo floats prior to deployment and set up the raw data stream. EL and CP developed the BGC-Argo float version used in this study and contributed to float preparation. CS handled BGC-Argo data archiving and distribution. All authors reviewed and approved the manuscript. 
Competing interests. The contact author has declared that neither they nor their co-authors have any competing interests.

Disclaimer. Publisher's note: Copernicus Publications remains neutral with regard to jurisdictional claims in published maps and institutional affiliations.

Special issue statement. This article is part of the special issue "Atmospheric deposition in the low-nutrient-low-chlorophyll (LNLC) ocean: effects on marine life today and in the future (ACP/BG interjournal SI)". It is not associated with a conference.

Acknowledgements. Phytoplankton pigment analyses were performed at the SAPIGH national HPLC analytical service at the Institut de la Mer de Villefranche (IMEV). We acknowledge the captains and crew of the Téthys and Pourquoi Pas? research vessels during the BOUSSOLE and PEACETIME cruises, as well as David Antoine, PI (principal investigator) of the BOUSSOLE project, and Cécile Guieu and Karine Desboeufs, PIs of the PEACETIME project. We thank the international Argo program and Coriolis project, which contributed to making the data freely and publicly available. Marin Cornec is also warmly thanked for useful discussion regarding biological production in SCM systems. We finally wish to thank the two anonymous reviewers and the co-editor-inchief for their useful comments and suggestions.

Financial support. This research has been supported by the PEACETIME program (https://doi.org/10.17600/17000300), a joint initiative of the MERMEX and ChArMEx components supported by CNRS-INSU, IFREMER, CEA and Météo-France as part of the program MISTRALS coordinated by INSU; PEACETIMEOC, supported by the French program CNES-TOSCA; remOcean, funded by ERC (grant no. 246777); and NAOS, funded by ANR Equipex (grant no. J11R107-F). Marie Barbieux was funded by a $\mathrm{PhD}$ grant from Sorbonne Université (Ecole Doctorale 129).

Review statement. This paper was edited by Chiara Santinelli and reviewed by two anonymous referees.

\section{References}

Ahn, Y.-H., Bricaud, A., and Morel, A.: Light backscattering efficiency and related properties of some phytoplankters, DeepSea Res. Pt. A, 39, 1835-1855, https://doi.org/10.1016/01980149(92)90002-B, 1992.

Allen, J. I., Somerfield, P. J., and Siddorn, J.: Primary and bacterial production in the Mediterranean Sea: a modelling study, J. Mar. Syst., 33/34, 473-495, https://doi.org/10.1016/S09247963(02)00072-6, 2002.

Álvarez, E., Morán, X. A. G., López-Urrutia, Á., and Nogueira, E.: Size-dependent photoacclimation of the phytoplankton community in temperate shelf waters (southern Bay of Biscay), Mar.
Ecol. Prog. Ser., 543, 73-87, https://doi.org/10.3354/meps11580, 2016.

Antoine, D., Morel, A., and André, J.-M.: Algal pigment distribution and primary production in the eastern Mediterranean as derived from coastal zone color scanner observations, J. Geophys. Res, 100, 16193-16209, https://doi.org/10.1029/95JC00466, 1995.

Antoine, D., André, J.-M., and Morel, A.: Oceanic primary production: 2. Estimation at global scale from satellite (Coastal Zone Color Scanner) chlorophyll, Global Biogeochem. Cy., 10, 57-69, https://doi.org/10.1029/95GB02832, 1996.

Antoine, D., D’Ortenzio, F., Hooker, S. B., Bécu, G., Gentili, B., Tailliez, D., and Scott, A. J.: Assessment of uncertainty in the ocean reflectance determined by three satellite ocean color sensors (MERIS, SeaWiFS and MODIS-A) at an offshore site in the Mediterranean Sea (BOUSSOLE project), J. Geophys. Res., 113, 1-22, https://doi.org/10.1029/2007JC004472, 2008.

Barber, R. T. and Hitling, A. K.: History of the study of plankton productivity, in: Phytoplankton Productivity: Carbon assimilation in marine and freshwater ecosystems, edited by: Williams, P. J. L. B., Thomas, D. N., and Reynolds, C. S., Blackwell Science, Oxford, 16-43, https://doi.org/10.1002/9780470995204, 2002.

Barbieux, M., Uitz, J., Bricaud, A., Organelli, E., Poteau, A., Schmechtig, C., Gentili, B., Penkerc'h, C., Leymarie, E., D'Ortenzio, F., and Claustre, H.: Assessing the variability in the relationship between the particulate backscattering coefficient and the chlorophyll a concentration from a global Biogeochemical-Argo database, J. Geophys. Res., 123, 12291250, https://doi.org/10.1002/2017JC013030, 2018.

Barbieux, M., Uitz, J., Bricaud, A., Organelli, E., Poteau, A., Schmechtig, C., Gentili, B., Penkerc'h, C., Leymarie, E., D'Ortenzio, F., and Claustre, H.: Assessing the variability in the relationship between the particulate backscattering coefficient and the chlorophyll $a$ concentration from a global Biogeochemical-Argo database, J. Geophys. Res., 123, 12291250, https://doi.org/10.1002/2017JC013030, 2018.

Barbieux, M., Uitz, J., Gentili, B., Pasqueron de Fommervault, O., Mignot, A., Poteau, A., Schmechtig, C., Taillandier, V., Leymarie, E., Penkerc'h, C., D'Ortenzio, F., Claustre, H., and Bricaud, A.: Bio-optical characterization of subsurface chlorophyll maxima in the Mediterranean Sea from a Biogeochemical-Argo float database, Biogeosciences, 16, 13211342, https://doi.org/10.5194/bg-16-1321-2019, 2019.

Barnes, M. and Antoine, D.: Proxies of community production derived from the diel variability of particulate attenuation and backscattering coefficients in the northwest mediterranean sea, Limnol. Oceanogr., 59, 2133-2149, https://doi.org/10.4319/lo.2014.59.6.2133, 2014.

Beckmann, A. and Hense, I.: Beneath the surface: Characteristics of oceanic ecosystems under weak mixing conditions - A theoretical investigation, Prog. Oceanogr., 75, 771-796, https://doi.org/10.1016/j.pocean.2007.09.002, 2007.

Behrenfeld, M. J. and Boss, E.: The beam attenuation to chlorophyll ratio: an optical index of phytoplankton physiology in the surface ocean?, Deep-Sea Res. Pt. I, 50, 1537-1549, https://doi.org/10.1016/j.dsr.2003.09.002, 2003.

Behrenfeld, M. J. and Boss, E.: Beam attenuation and chlorophyll concentration as alternative optical indices 
of phytoplankton biomass, J. Mar. Res., 64, 431-451, https://doi.org/10.1357/002224006778189563, 2006.

Behrenfeld, M. J., Marañón, E., Siegel, D. A., and Hooker, S. B.: Photoacclimation and nutrient-based model of light-saturated photosynthesis for quantifying oceanic primary production, Mar. Ecol. Prog. Ser., 228, 103-117, https://doi.org/10.3354/meps228103, 2002.

Behrenfeld, M. J., Boss, E., Siegel, D. A., and Shea, D. M.: Carbon-based ocean productivity and phytoplankton physiology from space, Global Biogeochem. Cy., 19, 1-14, https://doi.org/10.1029/2004GB002299, 2005.

Bernard, S., Probyn, T. A., and Quirantes, A.: Simulating the optical properties of phytoplankton cells using a two-layered spherical geometry, Biogeosciences Discuss., 6, 1497-1563, https://doi.org/10.5194/bgd-6-1497-2009, 2009.

Bethoux, J. P., Morin, P., Madec, C., and Gentili, B.: Phosphorus and nitrogen behaviour in the Mediterranean Sea, Deep-Sea Res., 39, 1641-1654, https://doi.org/10.1016/0198-0149(92)90053-V, 1992.

Bosc, E., Bricaud, A., and Antoine, D.: Seasonal and interannual variability in algal biomass and primary production in the Mediterranean Sea, as derived from 4 years of SeaWiFS observations, Global Biogeochem. Cy., 18, GB1005, https://doi.org/10.1029/2003GB002034, 2004.

Boss, E. and Zaneveld, J. R. V.: The effect of bottom substrate on inherent optical properties: Evidence of biogeochemical processes, Limnol. Oceanogr., 48, 346-354, https://doi.org/10.4319/lo.2003.48.1_part_2.0346, 2003.

Boss, E., Pegau, W. S., Lee, M., Twardowski, M., Shybanov, E., Korotaev, G., and Baratange, F.: Particulate backscattering ratio at LEO 15 and its use to study particle composition and distribution, J. Geophys. Res., 109, C01014, https://doi.org/10.1029/2002JC001514, 2004.

Bricaud, A., Morel, A., and Prieur, L.: Absorption by dissolved organic matter of the sea (yellow substance) in the UV and visible domains, Limnol. Oceanogr., 26, 43-53, https://doi.org/10.4319/lo.1981.26.1.0043, 1981.

Briggs, N., Perry, M. J., Cetinić, I., Lee, C., D’Asaro, E., Gray, A. M., and Rehm, E.: High-resolution observations of aggregate flux during a sub-polar North Atlantic spring bloom, Deep-Sea Res. Pt. I, 58, 1031-1039, https://doi.org/10.1016/j.dsr.2011.07.007, 2011

Briggs, N., Guðmundsson, K., Cetinić, I., D’Asaro, E., Rehm, E., Lee, C., and Perry, M. J.: A multi-method autonomous assessment of primary productivity and export efficiency in the springtime North Atlantic, Biogeosciences, 15, 4515-4532, https://doi.org/10.5194/bg-15-4515-2018, 2018.

Brunet C., Casotti R., Vantrepotte V., and Conversano F.: Vertical variability and diel dynamics of picophytoplankton in the Strait of Sicily, Mediterranean Sea, in summer, Mar. Ecol. Prog. Ser., 346, 15-26, https://doi.org/10.3354/meps07017, 2007.

Brunet, C., Casotti, R., and Vantrepotte, V.: Phytoplankton diel and vertical variability in photobiological responses at a coastal station in the Mediterranean Sea, J. Plank Res., 30, 645-654, https://doi.org/10.1093/plankt/fbn028, 2008.

Casotti, R., Landolfi, A., Brunet, C., D’Ortenzio, F., Mangoni, O., and Ribera d'Alcalaì, M.: Composition and dynamics of the phytoplankton of the Ionian Sea (eastern Mediterranean), J. Geo- phys. Res., 108, 1-19, https://doi.org/10.1029/2002JC001541, 2003.

Cetinić, I., Perry, M. J., Briggs, N. T., Kallin, E., D’ Asaro, E. A., and Lee, C. M.: Particulate organic carbon and inherent optical properties during 2008 North Atlantic Bloom Experiment, J. Geophys. Res., 117, 1-18, https://doi.org/10.1029/2011JC007771, 2012.

Cetinić, I., Perry, M. J., D’Asaro, E., Briggs, N., Poulton, N., Sieracki, M. E., and Lee, C. M.: A simple optical index shows spatial and temporal heterogeneity in phytoplankton community composition during the 2008 North Atlantic Bloom Experiment, Biogeosciences, 12, 2179-2194, https://doi.org/10.5194/bg-122179-2015, 2015.

Chavez, F. P., Messié, M., and Pennington, J. T.: Marine Primary Production in Relation to Climate Variability and Change, Annu. Rev. Mar. Sci., 3, 227-260, https://doi.org/10.1146/annurev.marine.010908.163917, 2013.

Claustre, H.: The trophic status of various oceanic provinces as revealed by phytoplankton pigment signatures, Limnol. Oceanogr. 39, 1206-1210, https://doi.org/10.4319/lo.1994.39.5.1206, 2014.

Claustre, H., Morel, A., Babin , M., Cailliau, C., Marie, D., Marty, J.-C., Tailliez, D., and Vaulot, D.: Variability in particle attenuation and chlorophyll fluorescence in the tropical Pacific: Scales, patterns, and biogeochemical implications, J. Geophys. Res. 104, 3401-3422, https://doi.org/10.1029/98JC01334, 1999.

Claustre, H., Bricaud, A., Babin, M., Bruyant, F., Guillou, L., Le Gall, F., Marie, D., and Partensky, F.: Diel variations in Prochlorococcus optical properties, Limnol. Oceanogr., 47, 1637-1647, https://doi.org/10.4319/lo.2002.47.6.1637, 2002.

Claustre, H., Huot, Y., Obernosterer, I., Gentili, B., Tailliez, D., and Lewis, M.: Gross community production and metabolic balance in the South Pacific Gyre, using a non intrusive bio-optical method, Biogeosciences, 5, 463-474, https://doi.org/10.5194/bg5-463-2008, 2008.

Claustre, H., Johnson, K. S., and Takeshita, Y.: Observing the Global Ocean with Biogeochemical-Argo, Annual Rev. Mar. Sci., 12, 23-48, https://doi.org/10.1146/annurev-marine-010419010956, 2020.

Cloern, J. E.: The relative importance of light and nutrient limitation of phytoplankton growth: A simple index of coastal ecosystem sensitivity to nutrient enrichment, Aquat. Ecol., 33, 3-16, https://doi.org/10.1023/A:1009952125558, 1999.

Cornec, M., Claustre, H., Mignot, A., Guidi, L., Lacour, L., Poteau, A., D'Ortenzio, F., Gentili, B., and Schmechtig, C.: Deep chlorophyll maxima in the global ocean: occurrences, drivers and characteristics, Global Biogeochem. Cy., 35, e2020GB006759, https://doi.org/10.1029/2020GB006759, 2021.

Corno, G., Letelier, R. M., Abbott, M. R., and Karl, D. M.: Assessing primary production variability in the North $\mathrm{Pa}-$ cific Subtropical Gyre: A comparison of Fast Repetition Rate Fluorometry and ${ }^{14} \mathrm{C}$ measurements, J. Phycol., 42, 51-60, https://doi.org/10.1111/j.1529-8817.2006.00163.x, 2005.

Crombet, Y., Leblanc, K., Quéguiner, B., Moutin, T., Rimmelin, P., Ras, J., Claustre, H., Leblond, N., Oriol, L., and Pujo-Pay, M.: Deep silicon maxima in the stratified oligotrophic Mediterranean Sea, Biogeosciences, 8, 459-475, https://doi.org/10.5194/bg-8459-2011, 2011 
Cullen, J. J.: The deep chlorophyll maximum: comparing vertical profiles of chlorophyll $a$, Can. J. Fish. Aquat. Sci., 39, 791-803, https://doi.org/10.1139/f82-108, 1982.

Cullen, J. J.: Subsurface chlorophyll maximum layers: enduring enigma or mystery solved?, Anni. Rev. Mar. Sci., 7, 207-239, https://doi.org/10.1146/annurev-marine-010213-135111, 2015.

Cullen, J. J. and Lewis, M. R.: Biological processes and optical measurements near the sea surface: Some issues relevant to remote sensing, J. Geophys. Res., 100, 13255-13266, https://doi.org/10.1029/95JC00454, 1995.

Cullen, J. J., Lewis, M. R., Davis, C. O., and Barber, R. T.: Photosynthetic characteristics and estimated growth rates indicate grazing is the proximate control of primary production in the equatorial Pacific, J. Geophys. Res., 97, 639-654, https://doi.org/10.1029/91JC01320, 1992.

Dandonneau, Y.: Measurement of in situ profiles of primary production using an automated sampling and incubation device, ICES Mar. Sci. Sym., 197, 172-180, 1993.

de Boyer Montégut, C., Madec, G., Fischer, A. S., Lazar, A., and Iudicone, D.: Mixed layer depth over the global ocean: An examination of profile data and a profile-based climatology, J. Geophys. Res., 109, 1-20, https://doi.org/10.1029/2004JC002378, 2004.

del Giorgio P. A. and Duarte C. M.: Respiration in the open ocean, Nature, 420, 37984, https://doi.org/10.1038/nature01165, 2002.

Di Cicco, A., Sammartino, M., Marullo, S., and Santoleri, R.: Regional empirical algorithms for an improved identification of phytoplankton functional types and size classes in the Mediterranean Sea using satellite data, Front. Mar. Sci., 4126, 1-18, https://doi.org/10.3389/fmars.2017.00126, 2017.

D’Ortenzio, F. and Ribera d'Alcalà, M.: On the trophic regimes of the Mediterranean Sea: a satellite analysis, Biogeosciences, 6, 139-148, https://doi.org/10.5194/bg-6-139-2009, 2009.

Duarte, C. M. and Agusti S.: The $\mathrm{CO}_{2}$ balance of unproductive aquatic ecosystems, Science, 281, 5374, https://doi.org/10.1126/science.281.5374.234, 1998.

Dubinsky, Z. and Stambler, N.: Photoacclimation processes in phytoplankton: mechanisms, consequences, and applications, Aquat. Microb. Ecol., 56, 163-176, https://doi.org/10.3354/ame01345, 2009.

Dugdale, R. C. and Wilkerson, F. P.: Nutrient sources and primary production in the Eastern Mediterranean, Oceanol. Acta, No. SP, 1988.

Durand, M. D. and Olson, R. J.: Contributions of phytoplankton light scattering and cell concentration changes to diel variations in beam attenuation in the equatorial pacific from flow cytometric measurements of pico-, ultra and nanoplankton, Deep-Sea Res. Pt. II, 43, 891-906, https://doi.org/10.1016/09670645(96)00020-3, 1996.

Durand, M. D. Green, R. E., Sosik, H. M., and Olson, R. J.: Diel Variations in Optical Properties of Micromonas Pusilla (Prasinophyceae), J. Phycol., 38, 1132-1142, https://doi.org/10.1046/j.1529-8817.2002.02008.x, 2002.

Estapa, M. L., Buesseler, K., Boss, E., and Gerbi, G.: Autonomous, high-resolution observations of particle flux in the oligotrophic ocean, Biogeosciences, 10, 5517-5531, https://doi.org/10.5194/bg-10-5517-2013, 2013.

Falkowski, P. G.: Ocean Science: The power of plankton, Nature, 483, S17-S20, https://doi.org/10.1038/483S17a, 2012.
Fennel, K. and Boss, E.: Subsurface maxima of phytoplankton and chlorophyll: Steady-state solutions from a simple model, Limnol. Oceanogr., 48, 1521-1534, https://doi.org/10.4319/lo.2003.48.4.1521, 2003.

Field, C. B., Behrenfeld, M. J., Randerson, J. T., and Falkowski, P.: Primary production of the biosphere: integrating terrestrial and oceanic components, Science, 281, 237-240, https://doi.org/10.1126/science.281.5374.237, 1998.

Fitzwater, S. E., Knauer, G. A., and Martin, J. H.: Metal contamination and its effect on primary production measurements, Limnol. Oceanogr., 27, 44-551, https://doi.org/10.4319/lo.1982.27.3.0544, 1982.

Fumihiko, A., Turki, A., Pascual, A., et al.: Argo float data and metadata from Global Data Assembly Centre (Argo GDAC) [data set], https://doi.org/10.17882/42182, 2021.

Gardner, W. D., Mishonov, A. V., and Richardson, M. J.: Global POC concentrations from in-situ and satellite data, Deep-Sea Res. Pt. II, 53, 718-740, https://doi.org/10.1016/j.dsr2.2006.01.029, 2006.

Geider, R. J.: Light and temperature dependence of the carbon to chlorophyll a ratio in microalgae and cyanobacteria: Implications for physiology and growth of phytoplankton, New Phytol., 106, 1-34, https://doi.org/10.1111/j.1469-8137.1987.tb04788.x, 1987.

Geider, R. J., MacIntyre, H. L., and Kana T. M.: Dynamic model of phytoplankton growth and acclimation: Responses of the balanced growth rate and the chlorophyll $a$ : carbon ratio to light, nutrient-limitation and temperature, Mar. Ecol. Prog. Ser., 148, 187-200, https://doi.org/10.3354/meps148187, 1997.

Gernez, P., Antoine, D., and Huot, Y.: Diel cycles of the particulate beam attenuation coefficient under varying trophic conditions in the northwestern Mediterranean Sea: Observations and modeling, Limnol. Oceanogr., 56, 17-36, https://doi.org/10.4319/lo.2011.56.1.0017, 2011.

Gitelson, A., Karnieli, A., Goldman, N., Yacobi, Y. Z., and Mayo, M.: Chlorophyll estimation in the Southeastern Mediterranean using CZCS images: adaptation of an algorithm and its validation, J. Mar. Syst., 9, 283-290, https://doi.org/10.1016/S09247963(95)00047-X, 1996.

Guieu, C., D’Ortenzio, F., Dulac, F., Taillandier, V., Doglioli, A., Petrenko, A., Barrillon, S., Mallet, M., Nabat, P., and Desboeufs, K.: Introduction: Process studies at the air-sea interface after atmospheric deposition in the Mediterranean Sea - objectives and strategy of the PEACETIME oceanographic campaign (May-June 2017), Biogeosciences, 17, 5563-5585, https://doi.org/10.5194/bg-17-5563-2020, 2020a.

Guieu, C., Desboeufs, K., Albani, S., Alliouane, S., Aumont, O., Barbieux, M., Barrillon, S., Baudoux, A.-C., Berline, L., Bhairy, N., Bigeard, E., Bloss, M., Bressac, M., Brito, J., Carlotti, F., de Lieg, G., Dinasquet, J., Djaoudi, K., Doglioli, A., D’Ortenzio, F., Doussin, J.-F., Duforet, L., Dulac, F., Dutay, J.-C., Engel, A., Feliu-Brito, G., Ferre, H., Formenti, P., Fu, F., Garcia, D., Garel, M., Gazeau, F., Giorio, C., Gregori, G., Grisoni, J.-M., Guasco, S., Guittonneau, J., Haëntjens, N., Heimburger, L.E., Helias, S., Jacquet, S., Laurent, B., Leblond, N., Lefevre, D., Mallet, M., Marañón, E., Nabat, P., Nicosia, A., Obernosterer, I., Perez Lorenzo, M., Petrenko, A., Pulido-Villena, E., Raimbault, P., Ridame, C., Riffault, V., Rougier, G., Rousselet, L., Roy-Barman, M., Saiz-Lopez, A., Schmechtig, C., Sel- 
legri, K., Siour, G., Taillandier, V., Tamburini, C., Thyssen, M., Tovar-Sanchez, A., Triquet, S., Uitz, J., Van Wambeke, F., Wagener, T., and Zaencker, B.: Biogeochemical dataset collected during the PEACETIME cruise, SEANOE [data set], https://doi.org/10.17882/75747, 2020b.

González, N., Anadón, R., Mouriño, B., Fernández, E., Sinha, B., Escánez, J., and de Armas, D.: The metabolic balance of the planktonic community in the North Atlantic Subtropical Gyre: The role of mesoscale instabilities, Limnol. Oceanogr., 46, 946952, https://doi.org/10.4319/lo.2001.46.4.0946, 2001.

González, N., Anadón, R., and Marañón, E.: Large-scale variability of planktonic net community metabolism in the Atlantic Ocean: Importance of temporal changes in oligotrophic subtropical waters, Mar. Ecol. Progr. Ser., 233, 21-30, https://doi.org/10.3354/meps233021, 2002.

Gordon, H. R. and McCluney, W. R.: Estimation of the Depth of Sunlight Penetration in the Sea for Remote Sensing, Appl. Opt., 14, 413-416, https://doi.org/10.1364/AO.14.000413, 1975.

Hense, I. and Beckmann, A.: Revisiting subsurface chlorophyll and phytoplankton distributions, Deep-Sea Res. Pt. I, 55, 1193-1199, https://doi.org/10.1016/j.dsr.2008.04.009, 2008.

Jacquet, S., Lennon, J.-F., Marie, D., and Vaulot, D.: Picoplankton population dynamics in coastal waters of the northwestern Mediterranean Sea, Limnol. Oceanogr., 43, 1916-1931, https://doi.org/10.4319/lo.1998.43.8.1916, 1998.

Juranek, L. W. and Quay, P. D.: In vitro and in situ gross primary and net community production in the North Pacific Subtropical Gyre using labeled and natural abundance isotopes of dissolved $\mathrm{O}_{2}$, Glob. Biogeochem. Cy., 19, GB3009, https://doi.org/10.1029/2004GB002384, 2005.

Karl, D. M., Laws, E. A., Morris, P., Williams, P. J. L. B, and Emerson, S.: Metabolic balance of the open sea, Nature, 426, 32-32, https://doi.org/10.1038/426032a, 2003.

Kemp, A. E. S. and Villareal, T. A.: High diatom production and export in stratified waters - A potential negative feedback to global warming, Prog. Oceanogr., 119, 4-23, https://doi.org/10.1016/j.pocean.2013.06.004, 2013.

Kemp, A. E. S. and Villareal, T. A.: The case of the diatoms and the muddled mandalas: Time to recognize diatom adaptations to stratified waters, Prog. Oceanogr., 167, 138-149, https://doi.org/10.1016/j.pocean.2018.08.002, 2018.

Kheireddine, M. and Antoine, D.: Diel variability of the beam attenuation and backscattering coefficients in the northwestern Mediterranean Sea (BOUSSOLE site), J. Geophys. Res., 119, 5465-5482, https://doi.org/10.1002/2014JC010007, 2014.

Kiefer, D. A., Olson, R. J., and Holm-Hansen, O.: Another look at the nitrite and chlorophyll maxima in the central North Pacific, Deep-Sea Res., 23, 1199-1208, https://doi.org/10.1016/00117471(76)90895-0, 1976

Kolber, Z. S. and Falkowski, P. G.: Use of active fluorescence to estimate phytoplankton photosynthesis in-situ, Limnol. Oceanogr., 38, 1646-1665, 1993.

Lacroix, G. and Nival, P.: Influence of meteorological variability on primary production dynamics in the Ligurian Sea (NW Mediterranean Sea) with a 1D hydrodynamic/biological model, J. Mar. Syst., 16, 23-50, https://doi.org/10.1016/S0924-7963(97)00098$5,1998$.

Lavigne, H., D’Ortenzio, F., Migon, C., Claustre, H., Testor, P., Ribera d'Alcalà, M., Lavezza, R., Houpert, L., and Prieur, L.:
Enhancing the comprehension of mixed layer depth control on the Mediterranean phytoplankton phenology, J. Geophys. Res.Ocean., 118, 3416-3430, 2013.

Lavigne, H., D’Ortenzio, F., Ribera D’Alcalà, M., Claustre, H., Sauzède, R., and Gacic, M.: On the vertical distribution of the chlorophyll a concentration in the Mediterranean Sea: a basinscale and seasonal approach, Biogeosciences, 12, 5021-5039, https://doi.org/10.5194/bg-12-5021-2015, 2015.

Letelier, R. M., Karl, D. M., Abbott, M. R., and Bidigare, R. R.: Light driven seasonal patterns of chlorophyll and nitrate in the lower euphotic zone of the North Pacific Subtropical Gyre, Limnol. Oceanogr., 2, 508-519, https://doi.org/10.4319/lo.2004.49.2.0508, 2004.

Litaker, R. W., Warner, V., Rhyne, C. F., Duke, C. S., Kenney, B. E., Ramus, J., and Tester, P. A.: Effect of diel and interday variations in light on the cell division pattern and in situ growth rates of the bloom-forming dinoflagellate Heterocapsa triquetra, Mar. Ecol. Prog. Ser., 232, 63-74, https://doi.org/10.3354/MEPS232063, 2002.

Loisel, H. and Morel, A.: Light scattering and chlorophyll concentration in case 1 waters: A reexamination, Limnol. Oceanogr., 5, 847-858, https://doi.org/10.4319/lo.1998.43.5.0847, 1998.

Loisel, H., Mériaux, X., Berthon, J.-F., and Poteau, A.: Investigation of the optical backscattering to scattering ratio of marine particles in relation to their biogeochemical composition in the eastern English Channel and southern North Sea, Limnol. Oceanogr. 52, 739-752, https://doi.org/10.4319/lo.2007.52.2.0739, 2007.

Loisel, H., Vantrepotte, V., Norkvist, K., Mériaux, X., Kheireddine, M., Ras, J., Pujo-Pay, M., Combet, Y., Leblanc, K., Dall'Olmo, G., Mauriac, R., Dessailly, D., and Moutin, T.: Characterization of the bio-optical anomaly and diurnal variability of particulate matter, as seen from scattering and backscattering coefficients, in ultra-oligotrophic eddies of the Mediterranean Sea, Biogeosciences, 8, 3295-3317, https://doi.org/10.5194/bg-8-32952011, 2011.

Longhurst, A., Sathyendranath, S., Platt, T., and Caverhill, C.: An estimate of global primary production in the ocean from satelite radiometer data, J. Plank. Res., 17, 1245-1271, https://doi.org/10.1093/plankt/17.6.1245, 1995.

Magazzu, G. and Decembrini, F.: Primary production, biomass and abundance of phototrophic picoplankton in the Mediterranean Sea: A review, Aquat. Microb. Ecol., 9, 97-104, https://doi.org/10.3354/ame009097, 1995.

Marañón, E., Van Wambeke, F., Uitz, J., Boss, E. S., Dimier, C., Dinasquet, J., Engel, A., Haëntjens, N., Pérez-Lorenzo, M., Taillandier, V., and Zäncker, B.: Deep maxima of phytoplankton biomass, primary production and bacterial production in the Mediterranean Sea, Biogeosciences, 18, 1749-1767, https://doi.org/10.5194/bg-18-1749-2021, 2021.

Marra, J., Langdon, C., and Knudson, C. A.: Primary production, water column changes, and the demise of a Phaeocystis bloom at the Marine Light-Mixed Layers site $\left(59^{\circ} \mathrm{N}, 21^{\circ} \mathrm{W}\right)$ in the northeast Atlantic Ocean, J. Geophys. Res., 100, 6633-6643, https://doi.org/10.1029/94JC01127, 1995.

Marty, J. C. and Chiavérini, J.: Hydrological changes in the Ligurian Sea (NW Mediterranean, DYFAMED site) during 1995-2007 and biogeochemical consequences, Biogeosciences, 7, 21172128, https://doi.org/10.5194/bg-7-2117-2010, 2010. 
Marty, J. C., Chiaveìrini, J., Pizay, M. D., and Avril, B.: Seasonal and interannual dynamics of nutrients and phytoplankton pigments in the western Mediterranean Sea at the DYFAMED timeseries station (1991-1999), Deep-Sea Res. Pt. II, 49, 1965-1985, https://doi.org/10.1016/S0967-0645(02)00022-X, 2002.

Mayot, N., D’Ortenzio, F., Ribera d'Alcalà, M., Lavigne, H., and Claustre, H.: Interannual variability of the Mediterranean trophic regimes from ocean color satellites, Biogeosciences, 13, 19011917, https://doi.org/10.5194/bg-13-1901-2016, 2016.

McClain, C. R., Signorini, S. R., and Christian, J. R.: Subtropical gyre variability observed by oceancolor satellites, Deep-Sea Res. Pt. II, 51, 281-301, https://doi.org/10.1016/j.dsr2.2003.08.002, 2004.

McGillicuddy Jr., D. J.: Mechanisms of Physical-BiologicalBiogeochemical Interaction at the Oceanic Mesoscale, Annu. Rev. Mar. Sci., 8-1, 125-159, 2016.

Mignot, A., Claustre, H., Uitz, J., Poteau, A., D’Ortenzio, F., and Xing, X.: Understanding the seasonal dynamics of phytoplankton biomass and the deep chlorophyll maximum in oligotrophic environments: A Bio-Argo float investigation, Global Biogeochem. Cy., 28, 856-876, https://doi.org/10.1002/2013GB004781, 2014.

Minas, H. J.: La distribution de l'oxygeÌne en relation avec la production primaire en Meìditerraneìe Nord-Occidentale, Mar. Biol., 7, 181-204, https://doi.org/10.1007/BF00367489, 1970.

Morel, A.: Light and marine photosynthesis: a spectral model with geochemical and climatological implications, Prog. Oceanogr., 26, 263-306, https://doi.org/10.1016/0079-6611(91)90004-6, 1991.

Morel, A. and André, J.-M.: Pigment distribution and primary production in the western Mediterranean as derived and modeled from coastal zone color scanner observations, J. Geophys. Res., 96, 12685-12698, https://doi.org/10.1029/91JC00788, 1991.

Morel, A., Antoine, D., Babin, M., and Dandonneau, Y.: Measured and modeled primary production in the northeast Atlantic (EUMELI JGOFS program): the impact of natural variations in photosynthetic parameters on model predictive skill, DeepSea Res. Pt. I, 43, 1273-1304, https://doi.org/10.1016/00796611(91)90004-6, 1996.

Moutier, W., Duforêt-Gaurier, L., Thyssen, M., Loisel, H., Mériaux, X., Courcot, L., Dessailly, D., Rêve, M.-H., Grégori, G., Alvain, S., Barani, A., Brutier, L., and Dugrnne, M.: Evolution of the scattering properties of phytoplankton cells from flow cytometry measurements, PLOS ONE, 12, e0181180, https://doi.org/10.1371/journal.pone.0181180, 2017.

Neukermans, G., Loisel, H., Mériaux, X., Astoreca, R., and McKee, D.: In situ variability of mass-specific beam attenuation and backscattering of marine particles with respect to particle size, density, and composition, Limnol. Oceanogr., 57, 124-144, https://doi.org/10.4319/lo.2012.57.1.0124, 2012.

Nielsen, E. S.: The Use of radio-active carbon $\left(\mathrm{C}^{14}\right)$ for measuring organic production in the sea, ICES J. Mar. Sci., 18, 117-140, https://doi.org/10.1093/icesjms/18.2.117, 1952.

Organelli, E., Bricaud, A., Antoine, D., and Matsuoka, A.: Seasonal dynamics of light absorption by chromophoric dissolved organic matter (CDOM) in the NW Mediterranean Sea (BOUSSOLE site), Deep-Sea Res., 91, 72-85, https://doi.org/10.1016/j.dsr.2014.05.003, 2014.
Organelli, E., Barbieux, M., Claustre, H., Schmechtig, C., Poteau, A., Bricaud, A., Boss, E., Briggs, N., Dall'Olmo, G., D’Ortenzio, F., Leymarie, E., Mangin, A., Obolensky, G., Penkerc'h, C., Prieur, L., Roesler, C., Serra, R., Uitz, J., and Xing, X.: Two databases derived from BGC-Argo float measurements for marine biogeochemical and bio-optical applications, Earth Syst. Sci. Data, 9, 861-880, https://doi.org/10.5194/essd-9-861-2017, 2017.

Organelli, E., Dall'Olmo, G., Brewin, R. J. W., Taran, G., Boss, E., and Bricaud, A.: The open-ocean missing backscattering is in the structural complexity of particles, Nat. Commun., 9, 5439, https://doi.org/10.1038/s41467-018-07814-6, 2018.

Oubelkheir, K. and Sciandra, A.: Diel variations in particle stocks in the oligotrophic waters of the Ionian Sea (Mediterranean), J. Mar. Syst., 74, 1-2, https://doi.org/10.1016/j.jmarsys.2008.02.008, 2008.

Oubelkheir, K., Claustre, H., Sciandra, A., and Babin, M.: Biooptical and biogeochemical properties of different trophic regimes in oceanic waters, Limnol. Oceanogr., 50, 1795-1809, https://doi.org/10.4319/lo.2005.50.6.1795, 2005.

Pasqueron de Fommervault, O., Migon, C., D’Ortenzio, F., Ribera d'Alcalà, M., and Coppola, L.: Temporal variability of nutrient concentrations in the northwestern Mediterranean Sea (DYFAMED time-series station), Deep-Sea Res. Pt. I, 100, 1-12, https://doi.org/10.1016/j.dsr.2015.02.006, 2015.

Polovina, J. J., Howell, E. A., and Abecassis, M.: Ocean's least productive waters are expanding, Geophys. Res. Lett., 35, L03618, https://doi.org/10.1029/2007GL031745, 2008.

Quay, P. D., Peacock, C., Björkman, K., and Karl, D. M.: Measuring primary production rates in the ocean: Enigmatic results between incubation and non-incubation methods at Station ALOHA, Glob. Biogeochem. Cy., 24, GB3014, https://doi.org/10.1029/2009GB003665, 2010.

Ras, J., Claustre, H., and Uitz, J.: Spatial variability of phytoplankton pigment distributions in the Subtropical South Pacific Ocean: comparison between in situ and predicted data, Biogeosciences, 5, 353-369, https://doi.org/10.5194/bg-5-353-2008, 2008.

Regaudie-de-Gioux, A., Lasternas, S., Agustí, S., and Duarte, C. M.: Comparing marine primary production estimates through different methods and development of conversion equations, Frontiers, 1, 19, https://doi.org/10.3389/fmars.2014.00019, 2014.

Roesler, C. S. and Boss, E.: In Situ Measurement of the Inherent Optical Properties (IOPs) and Potential for Harmful Algal Bloom Detection and Coastal Ecosystem Observations, in: Real-time coastal observing systems for marine ecosystem dynamics and harmful algal blooms: Theory, instrumentation and modelling, edited by: Babin, M., Roesler, C. S., and Cullen, J. J., UNESCO, ISBN 978-92-3-104042-9, 2008.

Roesler, C., Uitz, J., Claustre, H., Boss, E., Xing, X., Organelli, E., Briggs, N., Bricaud, A., Schmechtig, C., Poteau, A., D’Ortenzio, F., Ras, J., Drapeau, S., Haëntjens, N., and Barbieux, M.: Recommendations for obtaining unbiased chlorophyll estimates from in situ chlorophyll fluorometers: A global analysis of WET Labs ECO sensors, Limnol. Oceanogr.-Meth., 15, 572-585, https://doi.org/10.1002/lom3.10185, 2017.

Saba, V. S., Friedrichs, M. A. M., Carr, M.-E., Antoine, D., Armstrong, R. A., Asanuma, I., Aumont, O., Bates, N. R., Behrenfeld, M. J., Bennington, V., Bopp, L., Bruggeman, j., Buiten- 
huis, E. T., Church, M. J., Ciotti, A. M., Doney, S. C., Dowell, M., Dunne, J., Dutkiewicz, S., Gregg, W., Hoepffner, N., Hyde, K. J. W., Ishizaka, J., Kameda, T., Karl, D. M., Lima, I., Lomas, M. W., Marra, J., McKinley, G. A., Mélin, F., Moore, J. K., Morel, A., O'Reilly, J., Salihoglu, B., Scardi, M., Smyth, T. J., Tang, S., Tjiputra, J., Uitz, J., Vichi, M., Waters, K., Westberry, T. K., and Yool, A.: Challenges of modeling depthintegrated marine primary productivity over multiple decades: A case study at BATS and HOT, Glob. Biogeochem. Cy., 24, GB3020, https://doi.org/10.1029/2009GB003655, 2010.

Saba, V. S., Friedrichs, M. A. M., Antoine, D., Armstrong, R. A., Asanuma, I., Behrenfeld, M. J., Ciotti, A. M., Dowell, M., Hoepffner, N., Hyde, K. J. W., Ishizaka, J., Kameda, T., Marra, J., Mélin, F., Morel, A., O’Reilly, J., Scardi, M., Smith Jr., W. O., Smyth, T. J., Tang, S., Uitz, J., Waters, K., and Westberry, T. K.: An evaluation of ocean color model estimates of marine primary productivity in coastal and pelagic regions across the globe, Biogeosciences, 8, 489-503, https://doi.org/10.5194/bg8-489-2011, 2011.

Sarmiento, J. L. and Siegenthaler, U.: New production and the global carbon cycle, in: Primary productivity and biogeochemical cycles in the sea, Environmental Science Research, edited by: Falkowski, P. G., Woodhead A. D., and Vivirito K., Springer, Boston, MA, Vol. 43, https://doi.org/10.1007/978-1-4899-07622_18, 1992.

Sarmiento, J. L., Slater, R., Barber, R., Bopp, L., Doney, S. C., Hirst, A. C., Kleypas, J., Matear, R., Mikolajewicz, U., Monfray, P., Soldatov, V., Spall, S. A., and Stouffer, R.: Response of ocean ecosystems to climate warming, Global Biogeochem. Cy., 18, 123, https://doi.org/10.1029/2003GB002134, 2014.

Sathyendranath, S., Longhurst, A., Caverhill, C. M., and Platt, T.: Regionally and Seasonally Differentiated Primary Production in the North Atlantic, Deep-Sea Res. Pt. I, 42, 1773-1802, https://doi.org/10.1016/0967-0637(95)00059-F, 1995.

Sathyendranath, S., Stuart, V., Nair, A., Oka, K., Nakane, T., Bouman, H., Forget, M.-H., Maass, H., and Platt, T.: Carbon-to-chlorophyll ratio and growth rate of phytoplankton in the sea, Mar. Ecol. Prog. Ser., 383, 73-84, https://doi.org/10.3354/meps07998 2009.

Schmechtig, C., Poteau, A., Claustre, H., D'Ortenzio, F., and Boss, E.: Processing Bio-Argo chlorophyll a concentration at the DAC Level, Argo Data Management, 1-22, https://doi.org/10.13155/39468, 2015.

Schmechtig, C., Poteau, A., Claustre, H., D'Ortenzio, F., Dall'Olmo, G., and Boss, E.: Processing Bio-Argo particle backscattering at the DAC level Version, Argo Data Management, 1-13, https://doi.org/10.13155/39459, 2016.

Serret, P., Fernandez, E., Sostres, J. A., and Anadon, R.: Seasonal compensation of microbial production and respiration in a temperate sea, Mar. Ecol. Prog. Ser., 187, 43-57, https://doi.org/10.3354/meps187043, 1999.

Siegel, D. A., Dickey, T.D., Washburn, L., Hamilton, M. K., and Mitchell, B. G: Optical determination of particulate abundance and production variations in the oligotrophic ocean, Deep-Sea Res. Pt. A, 36, 211-222, https://doi.org/10.1016/01980149(89)90134-9, 1989

Signorini, S. R., Franz B. A., and McClain C. R.: Chlorophyll variability in the oligotrophic gyres: mecha- nisms, seasonality and trends, Front. Mar. Sci., 2, 1, https://doi.org/10.3389/fmars.2015.00001, 2015.

Siokou-Frangou, I., Christaki, U., Mazzocchi, M. G., Montresor, M., Ribera d'Alcalá, M., Vaqué, D., and Zingone, A.: Plankton in the open Mediterranean Sea: a review, Biogeosciences, 7, 1543 1586, https://doi.org/10.5194/bg-7-1543-2010, 2010.

Slade, W. H. and Boss, E.: Spectral attenuation and backscattering as indicators of average particle size, Applied Opt., 54, 72647277, https://doi.org/10.1364/AO.54.007264, 2015.

Smyth, T. J., Pemberton, K. L. , Aiken, J., and Geider, R. J.: A methodology to determine primary production and phytoplankton photosynthetic parameters from Fast Repetition Rate Fluorometry, J. Plank. Res., 26, 1337-1350, https://doi.org/10.1093/plankt/fbh124, 2004.

Stramska, M. and Dickey, T. D.: Variability of bio-optical properties of the upper ocean associated with diel cycles in phytoplankton population, J. Geophys. Res., 97, 17873-17887, https://doi.org/10.1029/92JC01570, 1992.

Stramski, D. and Kiefer, D. A.: Light scattering by microorganisms in the open ocean, Prog. Oceanogr., 28, 343-383, https://doi.org/10.1016/0079-6611(91)90032-H, 1991.

Stramski, D. and Reynolds, R. A.: Diel variations in the optical properties of a marine diatom, Limnol. Oceanogr., 38, 13471364, https://doi.org/10.4319/lo.1993.38.7.1347, 1993.

Stramski, D., Reynolds, R. A., Kahru, M., and Mitchell, B. G.: Estimation of particulate organic carbon in the ocean from satellite remote sensing, Science, 285, 239-242, https://doi.org/10.1126/science.285.5425.239, 1999.

Stramski, D., Bricaud, A., and Morel, A.: Modeling the inherent optical properties of the ocean based on the detailed composition of the planktonic community, Appl. Opt., 40, 2929-2945, https://doi.org/10.1364/AO.40.002929, 2001.

Stramski, D., Reynolds, R. A., Babin, M., Kaczmarek, S., Lewis, M. R., Röttgers, R., Sciandra, A., Stramska, M., Twardowski, M. S., Franz, B. A., and Claustre, H.: Relationships between the surface concentration of particulate organic carbon and optical properties in the eastern South Pacific and eastern Atlantic Oceans, Biogeosciences, 5, 171-201, https://doi.org/10.5194/bg5-171-2008, 2008.

Stramski, S., Boss, E., Bogucki, D., and Voss., K. J.: The role of seawater constituents in light backscattering in the ocean, Prog. Oceanogr., 61, 27-56, https://doi.org/10.1016/j.pocean.2004.07.001, 2004.

Suggett, D. J., Macintyre, H. L., and Geider, R. J.: Evaluation of biophysical and optical determinations of light absorption by photosystem II in phytoplankton, Limnol. Oceanogr. Meth., 316-332, https://doi.org/10.4319/lom.2004.2.316, 2004.

Sullivan, J., Twardowski, M., Ronald, S., Zaneveld, J. V., and Moore, C. C.: Measuring optical backscattering in water, in: Light scattering reviews, edited by: Kokhanovsky, A. A., Springer, Berlin, 7, 189-224, 2013.

Taillandier, V., Wagener, T., D’Ortenzio, F., Mayot, N., Legoff, H., Ras, J., Coppola, L., Pasqueron de Fommervault, O., Schmechtig, C., Diamond, E., Bittig, H., Lefevre, D., Leymarie, E., Poteau, A., and Prieur, L.: Hydrography and biogeochemistry dedicated to the Mediterranean BGC-Argo network during a cruise with RV Tethys 2 in May 2015, Earth Syst. Sci. Data, 10, 627-641, https://doi.org/10.5194/essd-10-627-2018, 2018. 
Turley, C. M., Bianchi, M., Christaki, U., Conan, P., Harris, J. R. W., Psarra, S., Ruddy, G., Stutt, E. D., Tselepides, A., and Van Wambeke, F.: Relationship between primary producers and bacteria in an oligotrophic sea - The Mediterranean and biogeochemical implications, Mar. Ecol. Progr. Ser., 193, 11-18, https://doi.org/10.3354/meps193011, 2000.

Twardowski, M. S., Boss, E., Macdonald, J. B., Pegau, W. S., Barnard, A. H., and Zaneveld, J. R. V.: A model for estimating bulk refractive index from the optical backscattering ratio and the implications for understanding particle composition in case I and case II waters, J. Geophys. Res., 106, 14129-14142, https://doi.org/10.1029/2000JC000404, 2001.

Uitz, J., Claustre, H., Morel, A., and Hooker, S. B.: Vertical distribution of phytoplankton communities in open ocean: An assessment based on surface chlorophyll, J. Geophys. Res., 111, 1-23, https://doi.org/10.1029/2005JC003207, 2006.

Uitz, J., Claustre, H., Gentili, B., and Stramski, D.: Phytoplankton class-specific primary production in the world's oceans: Seasonal and interannual variability from satellite observations, Global Biogeochem. Cy., 24, 1-19, https://doi.org/10.1029/2009gb003680, 2010.

Uitz, J., Stramski, D., Gentili, B., D’Ortenzio, F., and Claustre, H.: Estimates of phytoplankton class-specific and total primary production in the Mediterranean Sea from satellite ocean color observations, Global Biogeochem. Cy., 26, 1-10, https://doi.org/10.1029/2011gb004055, 2012.

Ulloa, O., Sathyendranath, S., and Platt, T.: Effect of the particlesize distribution on the backscattering ratio in seawater, Appl. Opt., 33, 7070-7077, https://doi.org/10.1364/AO.33.007070, 1994.

Vaulot, D. and Marie, D.: Diel variability of photosynthetic picoplankton in the equatorial Pacific, J. Geophys. Res., 104, 3297-3310, https://doi.org/10.1029/98JC01333, 1999.

Vidussi, F., Claustre, H., Manca, B. B., Luchetta, A., and Marty, J.-C.: Phytoplankton pigment distribution in relation to upper thermocline circulation in the eastern Mediterranean Sea during winter, J. Geophys. Res., 106, 19939-19956, https://doi.org/10.1029/1999JC000308, 2001.

Westberry, T., Behrenfeld, M. J., Siegel, D. A., and Boss, E.: Carbon-based primary productivity modeling with vertically resolved photoacclimation, Global Biogeoch. Cy., 222, 1-18, https://doi.org/10.1029/2007GB003078, 2008.
Westberry, T. K. Dall'Olmo, G., Boss, E., Behrenfeld, M., and Moutin, T.: Coherence of particulate beam attenuation and backscattering coefficients in diverse open ocean environments, Opt. Express, 18, 15419-15425, https://doi.org/10.1364/OE.18.015419, 2010.

White, A. E., Barone, B., Letelier, R. M., and Karl, D. M.: Productivity diagnosed from the diel cycle of particulate carbon in the North Pacific Subtropical Gyre, Geophys. Res. Lett., 44, 37523760, https://doi.org/10.1002/2016GL071607, 2017.

Whitmire, A. L., Boss, E., Cowles, T. J., and Pegau, W. S.: Spectral variability of the particulate backscattering ratio, Opt. Express, 15, 7019-7031, https://doi.org/10.1364/OE.15.007019, 2007.

Williams, P. J. leB. and Jenkinson, N. W.: A transportable microprocessor controlled precise Winkler titration suitable for field station and shipboard use, Limnol. Oceanogr., 27, 576-584, https://doi.org/10.4319/lo.1982.27.3.0576, 1982.

Williams, P. J. leB. and Purdie, D. A.: In vitro and in situ derived rates of gross production, net community production and respiration of oxygen in the oligotrophic subtropical gyre of the North Pacific Ocean, Deep-Sea Res. Pt. A, 38, 891-910, https://doi.org/10.1016/0198-0149(91)90024-A, 1991.

Williams, P. J. leB.: On the definition of plankton production terms, in: Measurement of primary production from the molecular to the global scale, edited by: Li, W. K. and Maestrini, Proceedings of a Symposium held in La Rochelle, 21-24 April 1992, ICES Marine Science Symposia, 197, ICES: Copenhagen, 287 pp., 1993.

Williams, P. J. leB., Morris, P. J., and Karl, D. M.: Net community production and metabolic balance at the oligotrophic ocean site, station ALOHA, Deep-Sea Res. Pt. I, 51, 1563-1578, https://doi.org/10.1016/j.dsr.2004.07.001, 2004.

Xing, X., Claustre, H., Blain, S., D’Ortenzio, F., Antoine, D., Ras, J., and Guinet, C.: Quenching correction for in vivo chlorophyll fluorescence acquired by autonomous platforms: A case study with instrumented elephant seals in the Kerguelen region (Southern Ocean), Limnol. Oceanogr.-Meth., 10, 483-495, https://doi.org/10.4319/lom.2012.10.483, 2012.

Yentsch, C. S. and Phinney, D. A.: A bridge between ocean optics and microbial ecology, Limnol. Oceanogr., 34, 1694-1705, https://doi.org/10.4319/lo.1989.34.8.1694, 1989.

Zhang, X., Hu, L., and He, M.-X.: Scattering by pure seawater: Effect of salinity, Opt. Express, 17, 5698-5710, https://doi.org/10.1364/OE.17.005698, 2009. 